Funded by Japan

Integrated Project

Azra/Tezin, Afghanistan

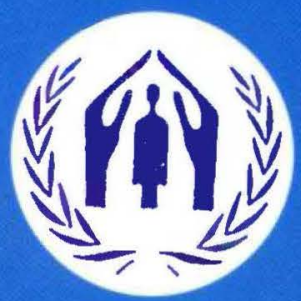

UNHCR

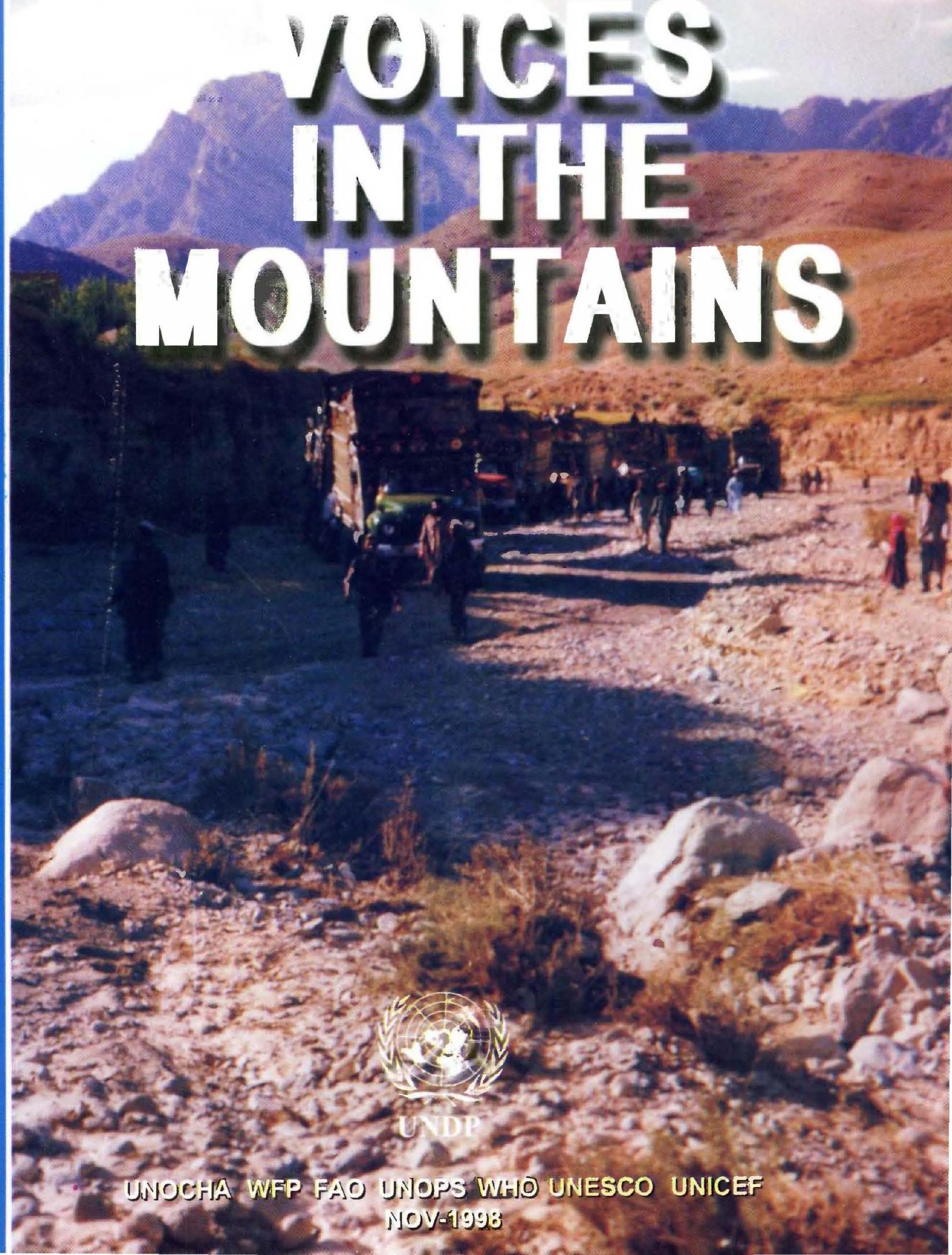




\section{VOLGAS \\ एज जUl \\ WOUNJANTS}

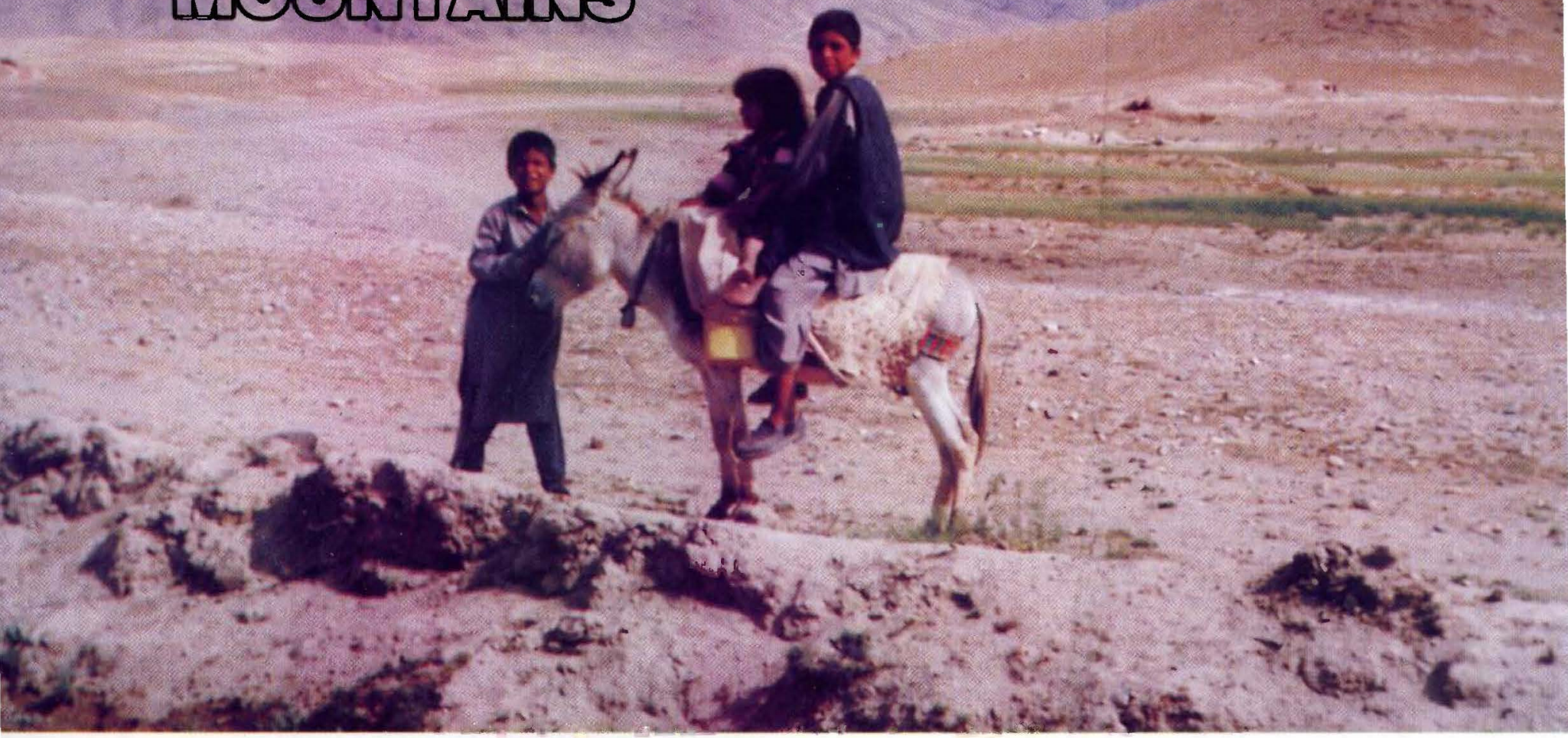

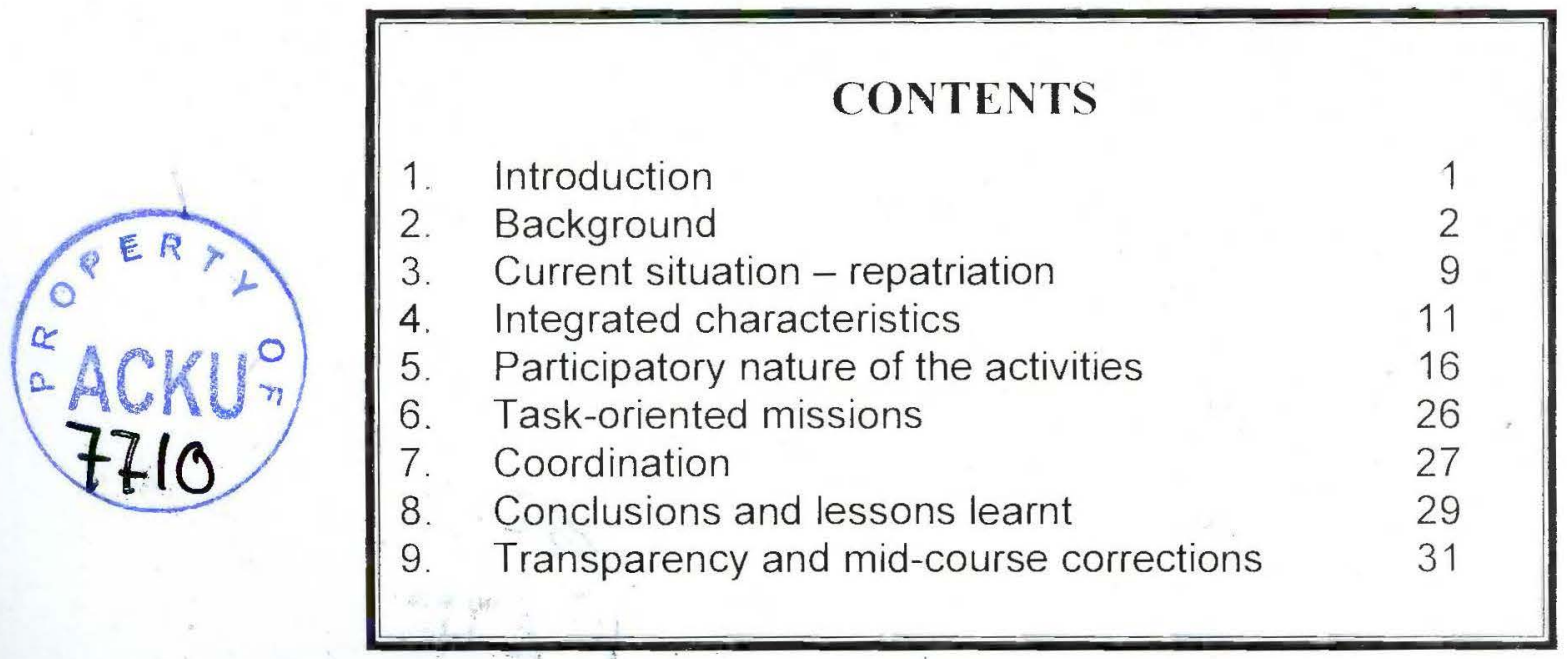




\section{Introduction}

Throughout its history the United Nations Organisation has focussed on the needs for new dimensions in development. 'Development for what?', Development for whom by whom?', 'Development by what means?, are some of the questions that have been raised. A number of answers have emerged as a sequel to these questions which emphasised that development should be needs-oriented, it should be endogenic, lead to self-reliance, ecologically sound, and lead to majority transformation.

The project on Azra and Tezin followed the

above principles and attempted to find

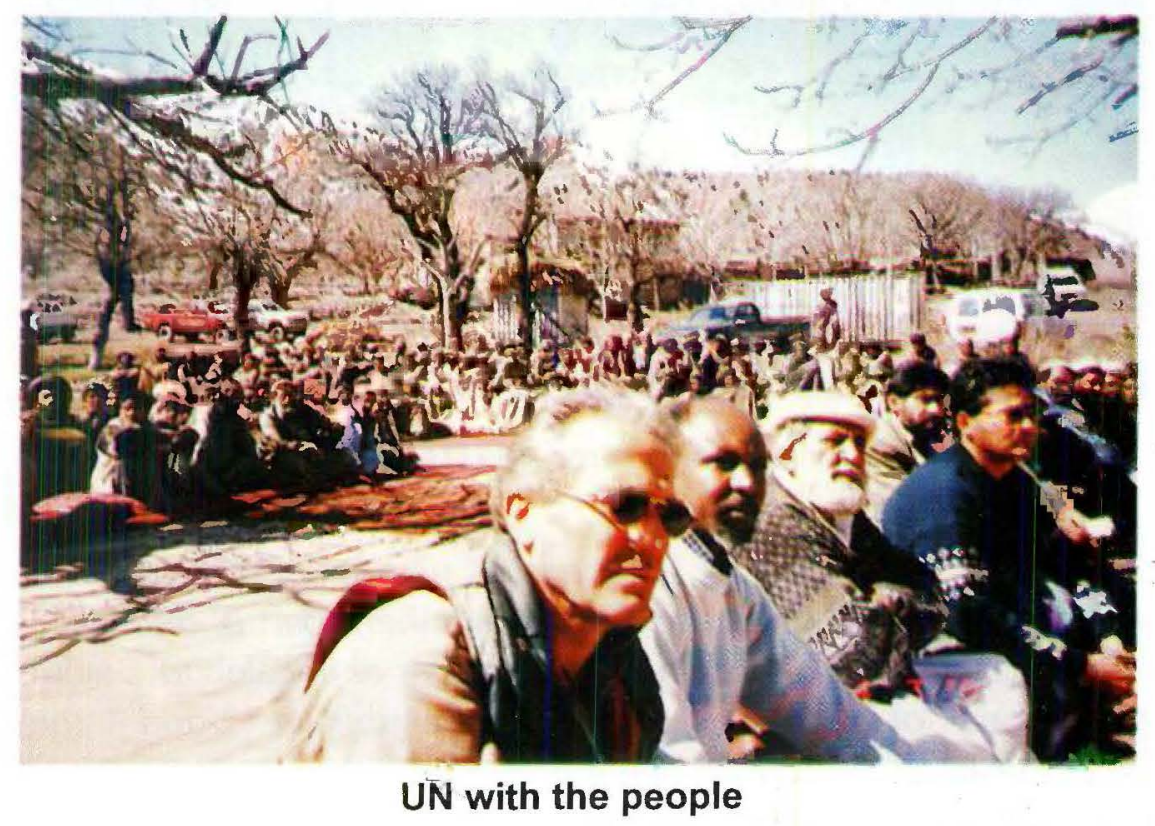

answers to the questions raised above. Afghanistan, a country at war for decades with refugee problems of enormous proportions, needs highly innovative approaches to attract and motivate the refugees to return home from the neighboring countries, who have borne the burden of hospitality, to a volatile situation. This integrated project launched by UNHCR in collaboration with a number of UN agencies, NGOs, local authorities, returnees and donors has attempted to add a new dimension to repatriation, following perhaps the age old Lao-tse's advice to rulers. 


\section{Background}

\section{Traditional Hospitality}

The village elders journey of almost six hours through a rugged terrain. Villages received the guests from UNHCR with 'salam', shaking of hands and warmly embracing each other in the mountains, at the boundary of their district, a traditional way of honouring guests. This was $40 \mathrm{~km}$ away from the village of Azra where distances do not matter for those who walk all the way, throughout life in the cold winters and sizzling summers. The warmth of the hosts, the beauty and the salubrious nature of the environment were invigorating, despite a tedious and treacherous

\section{Genesis of Azra/Tezin}

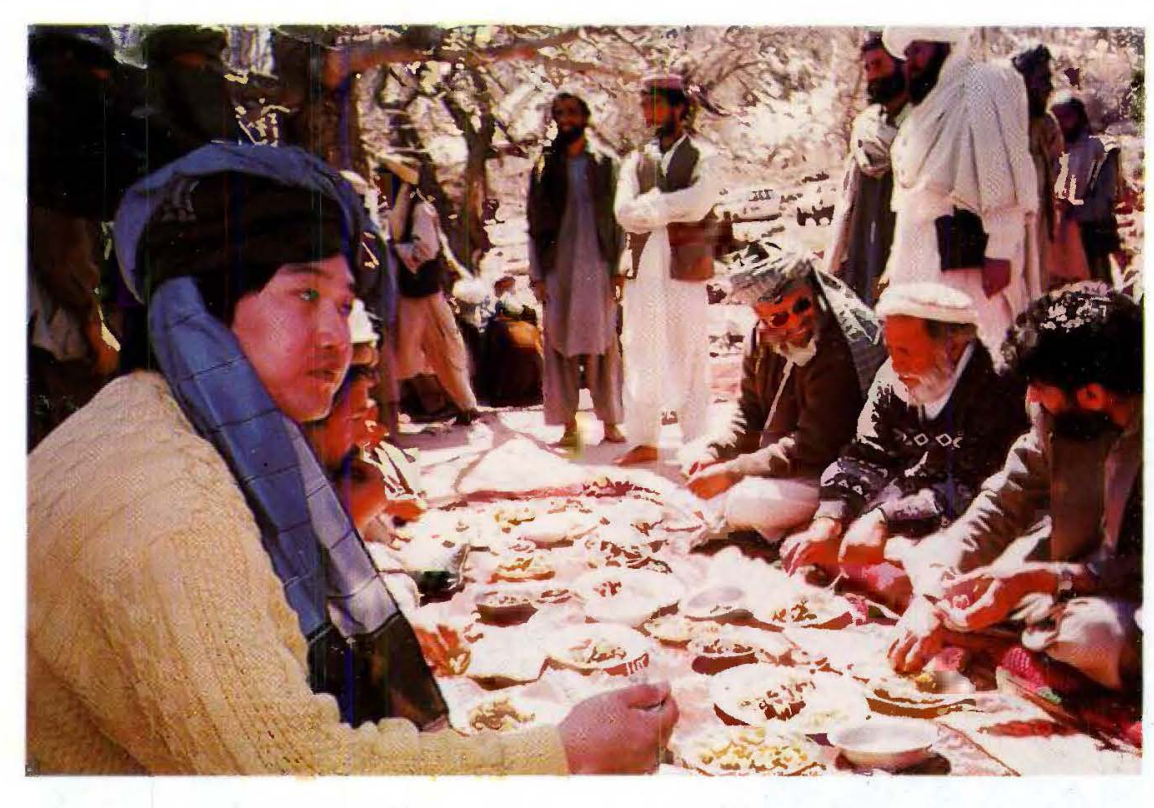
locked in between very high mountain walls, streams meandering in a leisurely mood and in no hurry to meet the Kabul river, provide unsurpassed scenic beauty. The people themselves have acquired these natural characteristics: friendly, hospitable and for them time and punctuality are not concerns.

Looking after guests

The key tribe of this area is the Ahmad Zai with four sub-tribes, namely Babar, Akbarkhel, Saifudinkhel and Razakhel. There is a reference to their mode of governance in earlier centuries in the book entitled 'Kingdom of Cabul' by Elphinstone,
(1815) 'Ahmedzyes who possess the east of Logur, and all the southern part of the valley of the Cabul river, as far as Jellalabad' were 'more decidely republican, and the sentiments of every individual must be taken before any measure of importance is decided 
on the interposition of the village in checking disturbances is more marked in many divisions, and in some they even compel the parties to submit to a Jeerga, or to quit the village'. According to the same source 'they are in perfect obedience to the King, the Khaun of the whole division, who is the representative of the sovereign, has much more influence than among the southern Solimanun Khail: and the whole division though it consists of 12,000 families, looks up to him as its head in all cases'. This gives an impression of the manner in which this part of the country was governed by the king and the influence of the community on decision making during the early centuries. A similar form of community-based decisionmaking still prevails.

\section{Difficult Passage}

Located at an elevation of 3000 meters both Azra and Tezin districts lie to the South East of Kabul in narrow valleys in the province of Logar. Both these districts can be approached through Kabul and Jalalabad. The river Surkhab, a tributary of the Kabul river, flows through some of the villages in the district of Azra, which at certain points forms the road to the villages of this district. The valleys of these two districts contain nearly 100 villages with a population of about 100,000 , prior to the invasion of the Soviets.

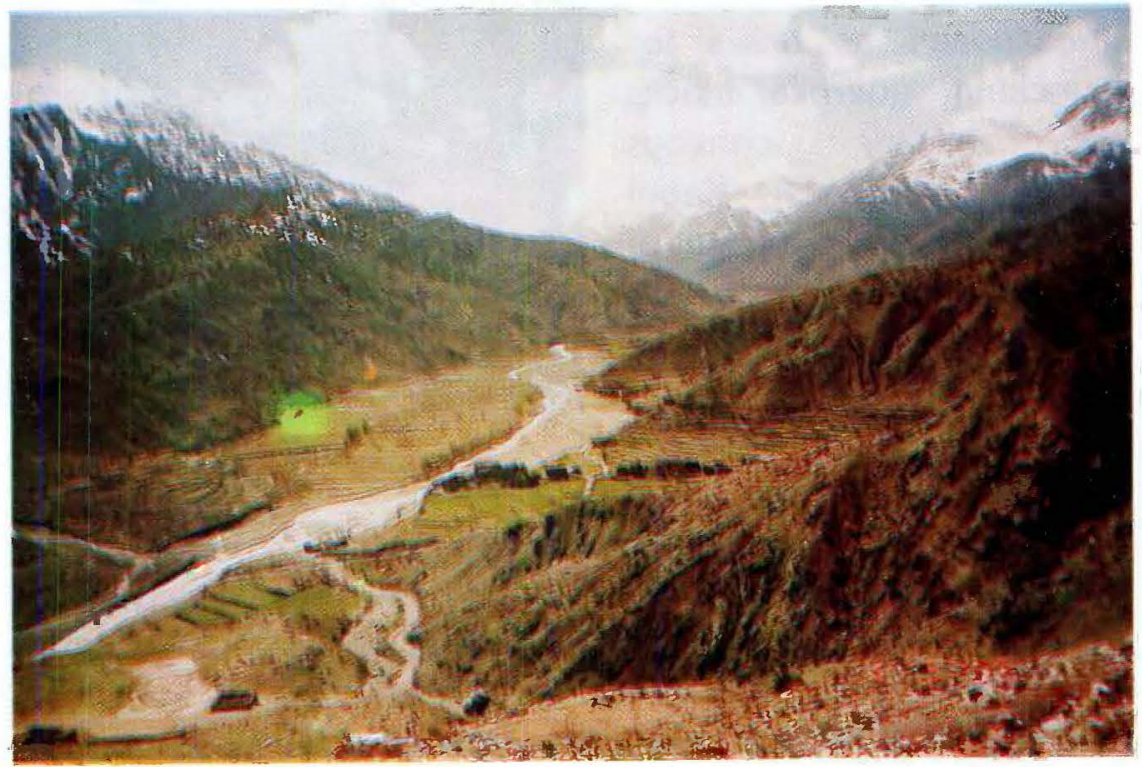

River road to Azra

It is a long hard drive to both Azra and Tezin, the remote and almost inaccessible districts of the Logar province in Afghanistan. Both are as poor and resourceless as many other parts of this war torn country. The approach to both districts is along winding, dusty roads that meander through the Hindukush mountains. The road which runs through a river bed for long distances receives a large number of tributaries with their ice cold waters. Going in a 4 
wheel-drive land cruiser on these roads is likely being in a bullock cart trundling up and down through the valleys and deep trenches.

\section{Despondency}

However, most of the population left these two districts during the Russian invasion. The village leaders proudly state that they were never conquered by foreigners on any occasion. These two districts, like elsewhere during the Soviet period, were used by the mujahadeen as bases for launching guerrilla attacks on military convoys travelling between Kabul and Jalalabad. As a result of the constant aerial attacks, everybody, except the active mujahadeen, left for Pakistan using camels,

donkeys and carts or travelling on foot carrying all their belongings.

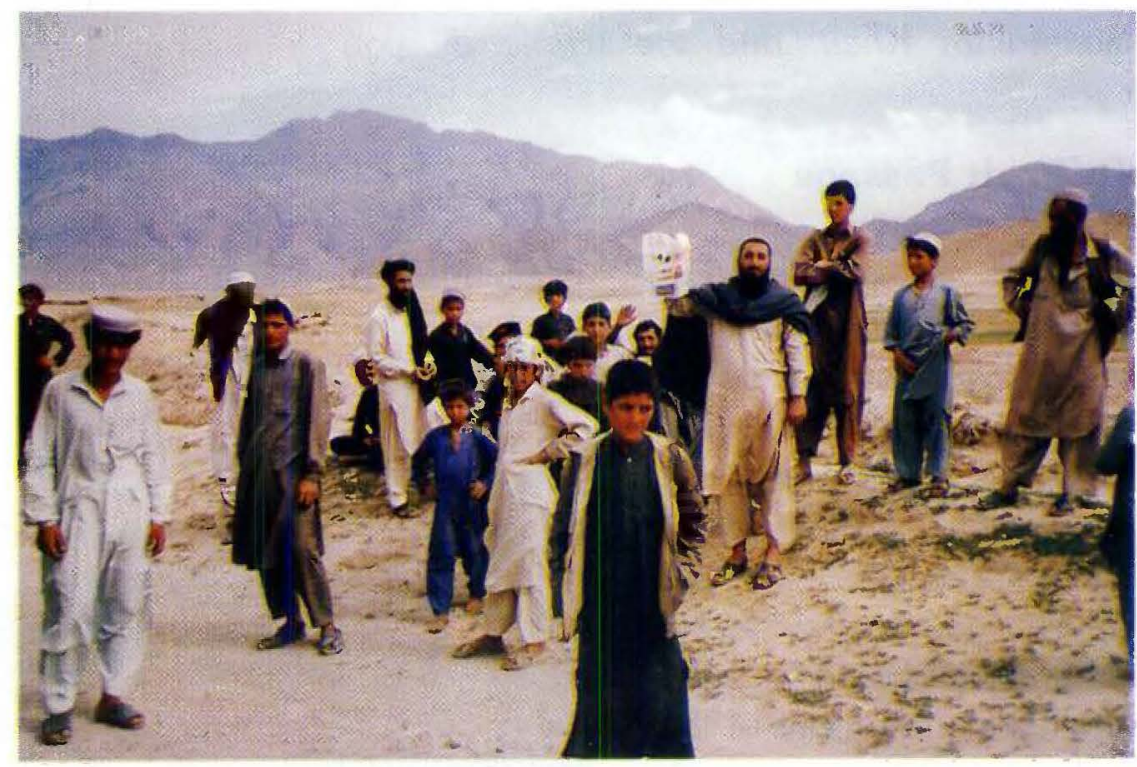

Despondency

By the time the Soviets left Afghanistan in 1992, virtually all the houses and other structures were destroyed. These included infrastructure related to agriculture, irrigation and road networks. Perhaps around 60 to 70 per cent of the agricultural land has become unusable. In addition mines have driven away many farmers from the lands. As a result only few of those who left these areas returned to their villages by early 1997. Most of the inhabitants of Tezin number around 10.000 in all continued to live in refugee camps in Peshawar.

The social life of these two districts is not very different from the rest of the country. What is difficult here is the additional natural hazards, which add to the already prevailing stresses. These areas are devoid of even the bare minimum facilities for a normal, settled life. There are no roads worth the name. 


\section{Erosion of resources}

When considering the total number of refugees, Afghanistan holds the world record numbering over 6 million in the early 1990s - one third of the total population. Although the number has decreased today to about 2.6 million it still remains the highest for any country. Thus, in terms of human potential, Afghanistan can function, at best, at half the capacity, as almost half the population is either incapacitated or out of the country. The seriousness of the issue relates to the development of human resources in the context of the future of Afghanistan. Other factors that aggravate the situation further, relate to a lack of infrastructure and logistical support for development activities. In relation to education which is the basis for human resource development, this includes professional development and skills training. Apart from this, there has been a constant drain from the country of the educated, professional and skilled persons since the 1980s. As a result the country has been running at a minimum level of efficiency and low capacity for nearly two decades. The simmering question today is how long Afghanistan can afford this erosion of valuable resources?.

\section{Rational strategies}

Such a scenario demands highly pro-active and innovative, multiple motivational approaches to development. It also requires that facilities provided should match or be closely equivalent to the basic services enjoyed by the refugees in the main countries of refuge, namely Pakistan and Iran. This would be one way to encourage refugees to return to their places of origin. It is with this vision that UNHCR conceived the idea and initiated an integrated developmental approach in Azra and Tezin districts. UNHCR hopes that this will become a symbol of sorts for more such undertakings in the future elsewhere in Afghanistan. All the while UN has only been reacting to situations where help is provided to those who have already returned to their homes. How did this change occur? Was it through design or accident? According to Surrendra Panday, UNHCR field officer in Kabul, "some refugees from Azra district contacted us last year (1997) in Islamabad and said that they were willing to return to their homes and farms if the UN could provide assistance in critical areas, like ensuring potable water, setting up clinics and providing help with: agricultural inputs". This contact gave birth to this innovative idea of getting the refugees to determine their needs for the first time on a shopping list. The experience will help to target other areas for similar repatriation programmes. 


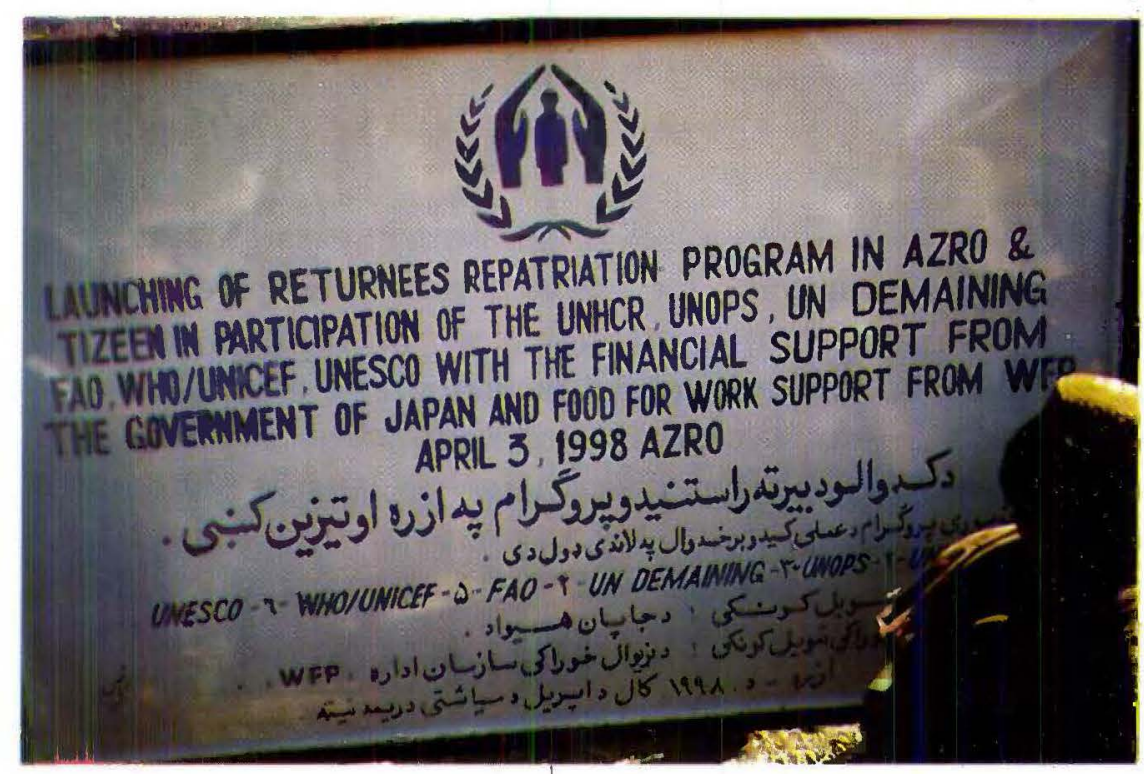

Partners in integration

Integration of all their needs in the context of their socioeconomic and cultural aspirations was thought to be a desirable approach. In this context, the concept of integration was thought out not only in terms of programmes and activities but in relation to institutions and their resources. In relation to programmes, UNHCR articulated integration as a way of juxtaposing the key elements of mutually reinforcing activities to provide greater understanding, benefit and impact for the returnees. For example better water facilities would help to improve health, lead to increased longevity and better outputs, in addition to increased participation of children in primary education etc. Institutional integration was defined as a way of sharing resources, both materials and experts, reducing duplication and waste and utilising given resources to the maximum.

\section{Assistance from the land of the rising sun}

Whatever the approaches, funds form the basis for take off. At a point when UNHCR was suffering its worst funding crisis for its Afghanistan programme for many years, Japan came to its rescue with a generous offer to provide funding and without conditionalities. Their only condition seems to be that benefits should go to all the returnees in Azra and Tezin without delay, efficiently and effectively. Thus these two districts would be the beneficiaries of US $\$ 2.2$ million from the government of Japan to various UN agencies and NGOs together under UNDP's Poverty Eradication and Community Empowerment (PEACE) programme. The Japanese contribution will make a huge difference to the UN. Azra and Tezin are particularly impoverished and underdeveloped areas. Without substantial aid in immediate rehabilitation needs as well as longer-term development, it would be extremely difficult for the refugees to return. It should be mentioned that Japan's contributions over the years to the humanitarian assistance programmes in Afghanistan since 1998 has been immense, amounting to more than US $\$ 125$ million. 
This offer has encouraged the UN agencies, NGOs support programmes and more specifically the refugees to organise themselves to return to their homeland. The contributions have been used to fund a wide range of rehabilitation priorities, identified through discussions with the refugee groups in Pakistan and community organisations in Azra and Tezin.

The Japanese Ambassador to Pakistan, Mr. Minoru Kubota, was very hopeful about the programme and was appreciative about the process when he said that "Japan has been actively involved in discussing the programme from the very beginning. We are funding it because we regard this kind of coordinated approach, in which UN agencies and NGOs work together with donors to make things happen, as the best way to achieve real and lasting results. This contribution illustrates our commitment to supporting the UN's efforts to bring peace to this war-torn region. It also reflects
Japan's own efforts to further the peace-building process". Japan is a country which understands and underscores peace-building and post-conflict reconstruction through practical experience and has been working for the same over the decades since World War Two.

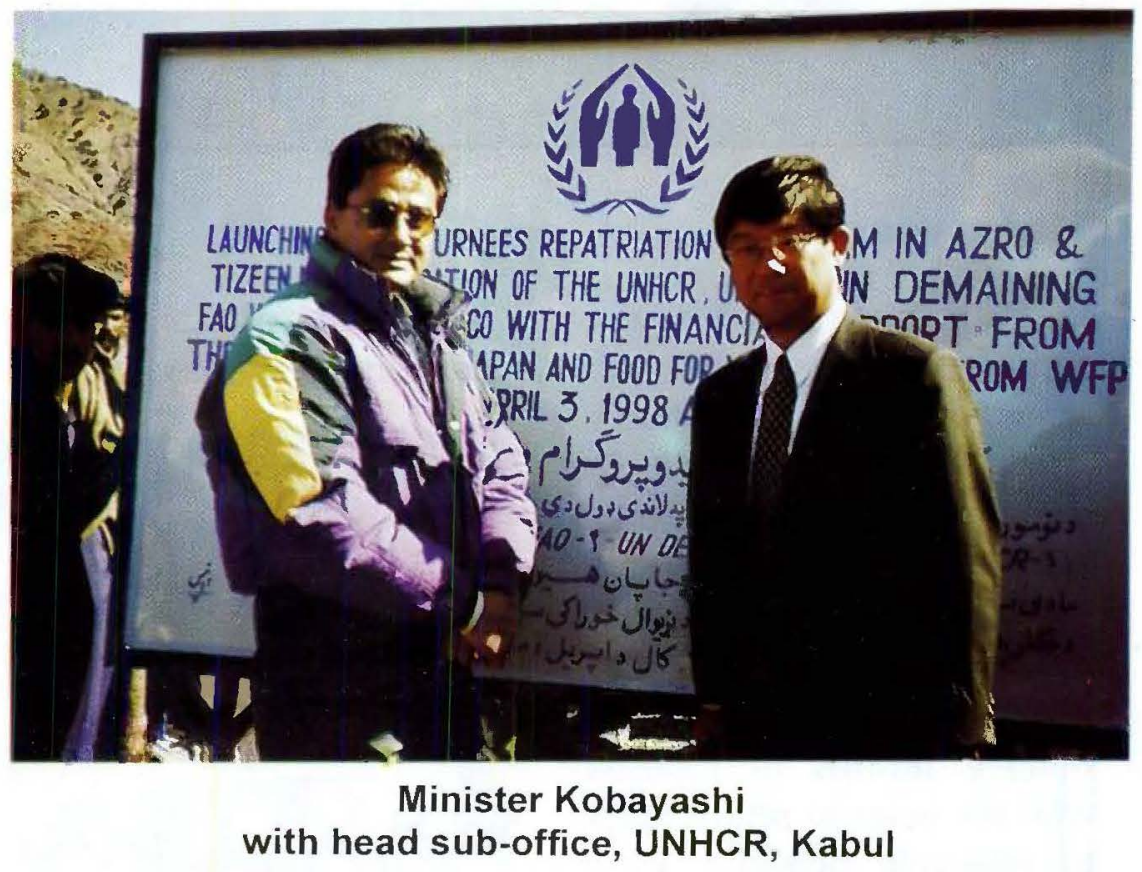

The UN Coordinator for Afghanistan, Mr. Alfrado Witschi-Cestari was emphatic about the innovative nature of the processes involved in this project when he stated that "this is the first time in the history of Afghanistan that a donor has taken a conscious decision by involving itself in monitoring and evaluating with the United Nations. It is also the first time that the refugees themselves have been consulted". 
Allocation of funds by agency and sector for this project is given in the diagrams below.

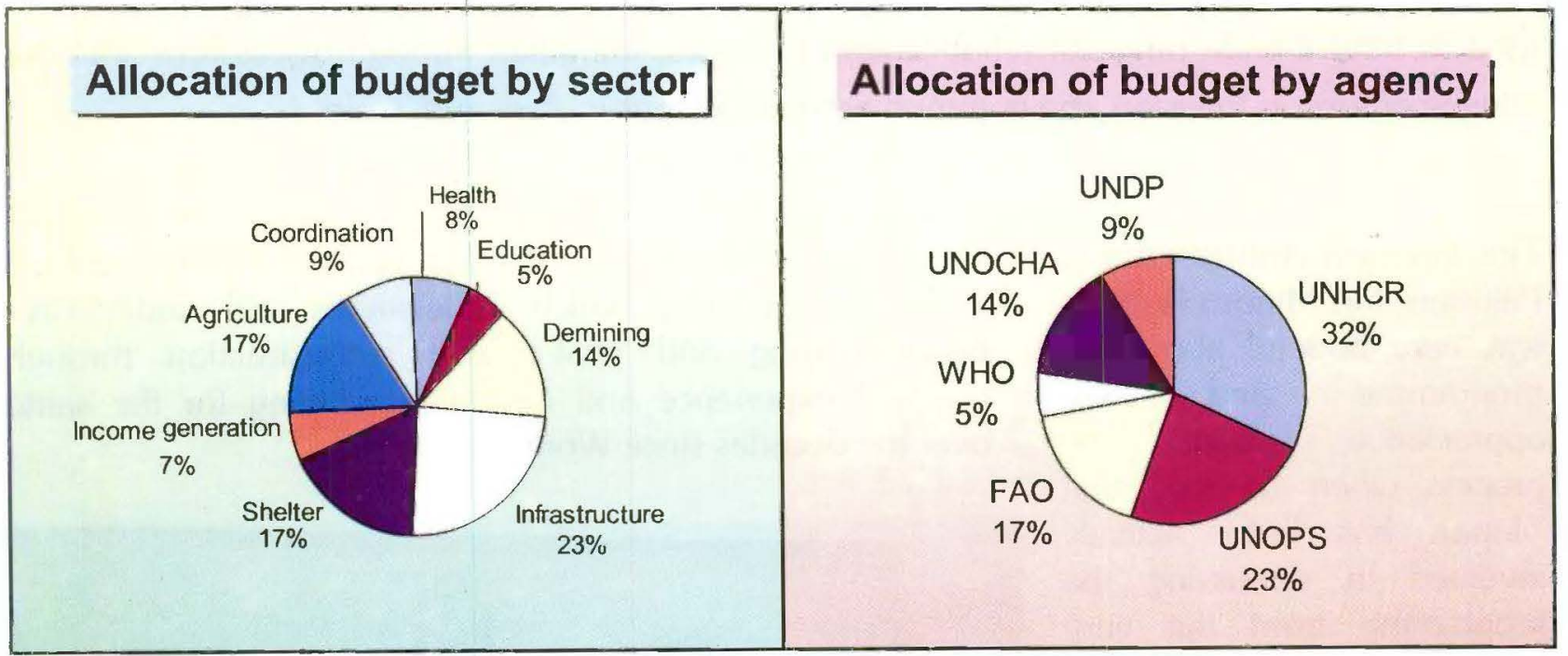

\section{Modus operandi}

UNHCR commenced its new strategy known as the targeted group repatriation in late 1997. It is parallel to the standard repatriation assistance that continues for individual families returning home. This new scheme involved identifying Afghan refugee groups in Pakistan who are keen to return home to relatively peaceful areas. But certain factors prevented them doing so, such as the mines, destroyed houses, malfunctioning irrigation systems, lack of economic opportunities,

non- availability of services such as schools, hospitals, road networks and other basic logistical needs.

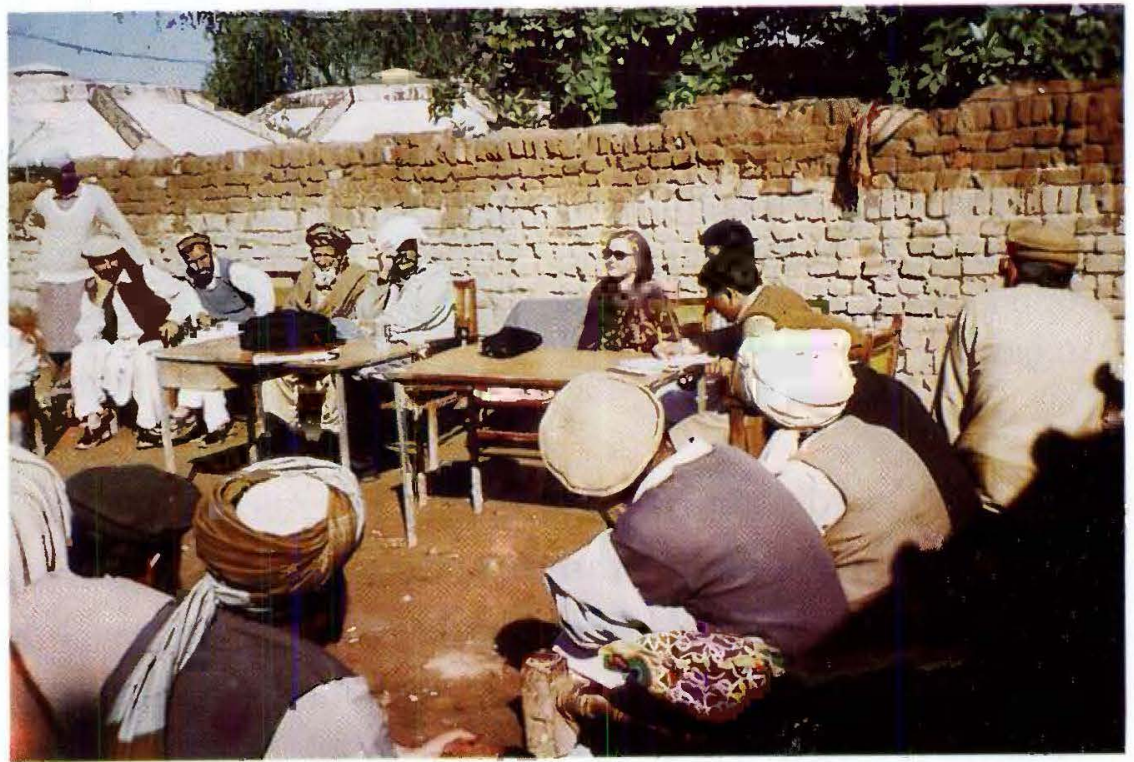

Discussions with elders about repatriation modalities 8 
The modus operandi was to service the needs of the key factors for repatriation. Thus one could see that this package is more demandoriented and is a collaborative effort of returnees with the respective UN agencies and their implementing partners. It is not one that is imposed by UNHCR alone.

The unique feature in this group repatriation relates to caring for the needs of the individual group. Thus the subsidies allotted for each group vary enormously depending on the distances they have to travel to their places of abode, extent of destruction and their dwellings etc. Sometimes the construction of a bridge across a river for the returnees might form a separate project - if , without it, the refugees would be unable to even reach their own village.

\section{** \\ 3. Current Situation - Repatriation}

\section{Azra district}

Since UNHCR launched the rehabilitation project in Azra in summer of 1997, refugees started to repatriate on a small scale. In December, the number of families living in Azra reached 774 (6966 individuals). After the winter. the movement continued at a slow pace. By April 1998, 146 families had returned.

The joint UN project initiated in April. 1998 produced a remarkable acceleration in the repatriation to Azra. Three hundred and thirty families (3,000 individuals) returned under UNHCR's group repatriation scheme and another 550 families (5.000 individuals) have spontaneously returned since April. The resident population has now reached around 1.800 families, which is about 54 per cent of the potential population of Azra origin. The total number of returnees to Azra this year which amounts to 9234 individuals consists of 40 per cent of the refugees from Azra.

Population of Azra

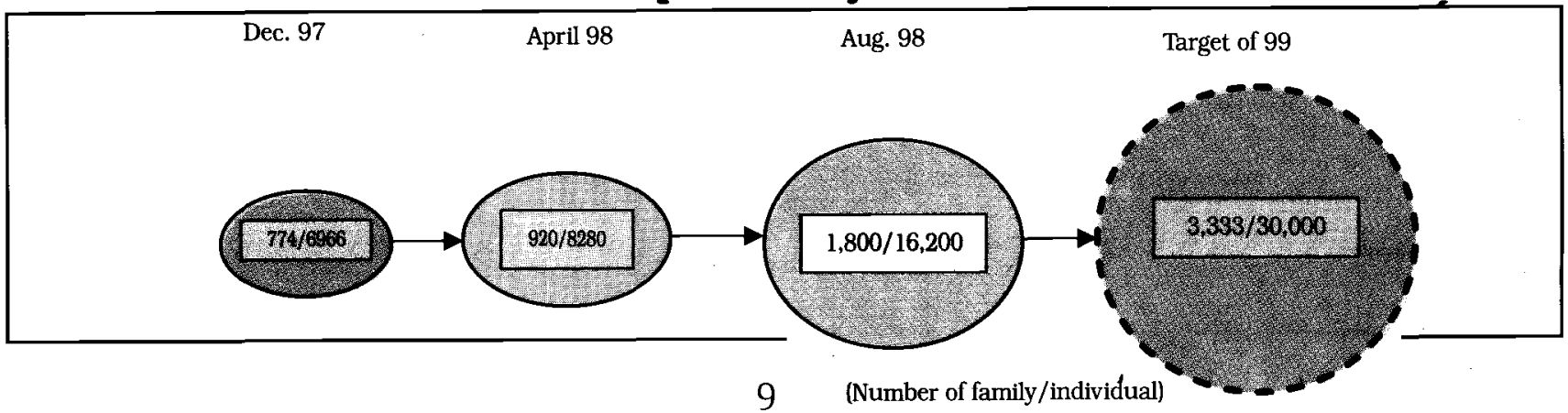




\section{Tezin district}

In the summer of 1997 there were only 21 families living in Tezin. Attracted by the UNHCR initiative in this area 133 families returned last autumn. Another 329 families returned this year under the group repatriation programme. In addition more returned on their own without registration or assistance. Currently around 300 families are attempting to settle down in their homeland. The figure has reached almost 85 percent of the target population.

\section{Population of Tezin}

Summer 97 Tatumn 97 Aug. 98

In addition to the returnees to Azra and Tenzin, 1200 families $(8,640)$ returned to neighbouring areas this year. Interviews with them revealed that they returned with high expectation of having the same kind of rehabilitation activities in the areas of return. This is the spill-over effect of the group repatriation programme

The Number of Returnees '98

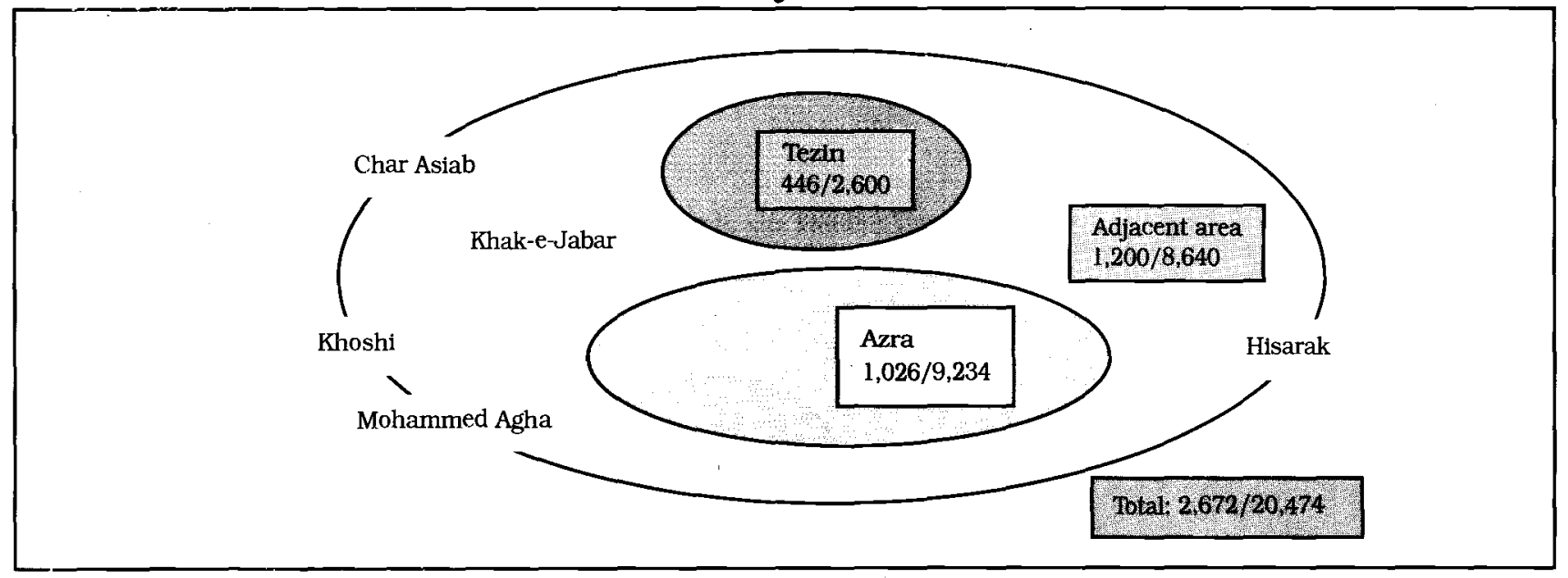




\section{Summary}

\begin{tabular}{|l|r|r|r|r|r|}
\hline & \multicolumn{1}{|c|}{ a) Azra } & b) Tezin & c) Total & d) Adjacent area & e) $=\mathrm{c}+\mathrm{d}$ \\
\hline Population'97 & $774 / 6,966$ & $154 / 900$ & $928 / 7,866$ & & \\
\hline Returnees '98 & $1,026 / 9,234$ & $446 / 2,600$ & $1,472 / 11,834$ & $1,200 / 8,640$ & $2,672 / 20,474$ \\
\hline $\begin{array}{l}\text { Total } \\
\text { Population }\end{array}$ & $1,800 / 16,200$ & $600 / 3,500$ & $2,400 / 19,700$ & & \\
\hline
\end{tabular}

$$
\text { stist }
$$

\section{Integrated Characteristics}

\section{Barefoot approaches}

It is similar to the scenes in the Wild West in $17^{\text {th }}$ century America, when people went to new environments in search of prosperity braving all the hazards, carrying everything they needed. Thus the first 17-truck convoy carrying 297 refugees perched on top of huge piles of baggage and all their belongings including animals and pets.

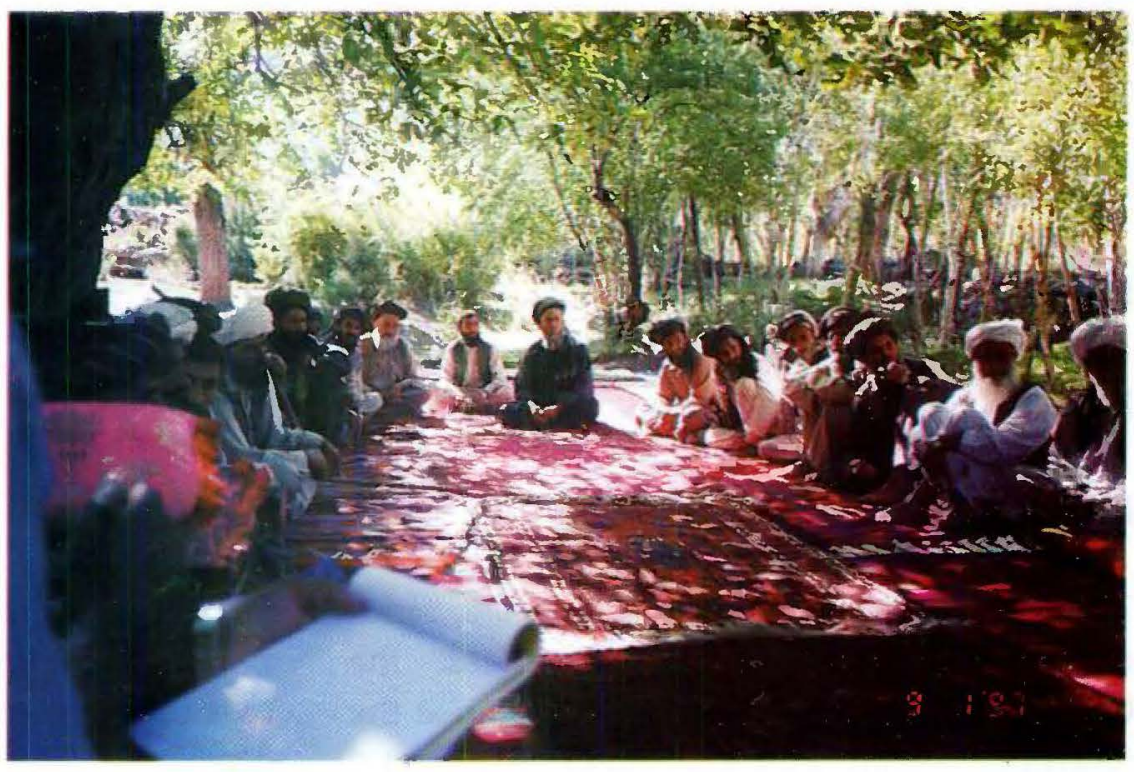

Discussions with elders - Azra

This is how they arrived in Tezin and Azaro in September 1997. Their long journey of more two days had brought them back to their soil which they left 17 years ago. Proud and confident that they were no longer exiles, they walked around on their original property as if they owned a kingdom. The welcome home by their relations and friends was emotional indeed which made them feel that they are genuinely wanted adding more strength to the community. 
UNHCR personnel were also elated and felt proud that they had been able to initiate an innovative programme successfully. On 15 May UNHCR's Representative in Pakistan, Jaques Mouchet said that "We are very pleased. In fact, the number of groups coming forward exceeds our expectations. We now have so many groups impatient to return that we may have to hire extra staff in Peshawar and Jalalabad to cope with the demand".

By May 1998 almost 5,000 refugees had returned under the group repatriation scheme, which is more than twice as that of the year 1997. In all the number returned to Afghanistan from Pakistan for the year May 1998 is more than 20,000. In addition, nearly 11,000 families amounting to 60 80,000 persons have expressed their willingness to return from all over Pakistan to their villages in Azra and Tezin.

The greatest number of returnees are departing from refugee villages in Pakistan's North Western Frontier Province for destinations in the bordering provinces of Afghanistan. The majority are Pashtuns originating from the rural districts in eastern and southern Afghanistan. The great majority of those who have returned over the past three years have been to the Taliban-controlled areas. The returnees feel safe in these areas than elsewhere and security is one of the key motivating factors for them to return.

\section{Grand strategy}

\section{Innovative initiatives}

\section{Pro-active mode of programming of the project}

Thinking locally and acting realistically, prior to the requests from the returnees, the UNHCR plan had in advance to make the returnees comfortable, acceptable and productive on their own soil. This included

\section{Creating a basis for re-integration}

This was a vital factor since most of the returnees have been away from their homes for nearly two decades. They were in exile where service facilities were relatively better. liaising with those concerned. The assistance package offered by UNHCR to the returnees was to attract more to return in due course . These pro-active approaches included the following.

The economic situation in Pakistan and Iran also offered better opportunities for improvement of the quality of life. Some of the returnees had never had contacts with 
Afghans inside Afghanistan. Further, they had not been able to comprehend the disadvantaged nature of the environments of Azra and Tezin with no facilities for transport and services. These were stresses for which the new arrivals had to be acclimatised otherwise they would feel frustrated and might even think of returning back as

\section{More to those who have less}

This is yet another principle on which UNHCR based its programmme. In this the neediest were given assistance to construct their houses. Moreover, the financial benefits were computed on the basis of refugees. The latter would be a disaster for UNHCR's repatriation programme. Hence the need for creating a basis for reintegration whereby the returnees were made to feel at home and also acceptable by those who have been living under very difficult conditions for nearly two decades.

distances and other constraints and not on a generalised basis. As a result, some were given extra assistance based on a principle of equity.

\section{Consultation and collaboration with partners}

Since this is an integrated project, involving many actors both in the UN system and the NGOs, elaborate discussions were held with all of them prior to the implementing of the project. This enabled them to understand the vision of the project and also to share the resources effectively. The partners included UNOPS - road reconstruction, flood protection, irrigation etc., UNCHS - water

\section{Sustainability through local resources}

To reduce costs and also use local skills and resources, competitive bidding was introduced under this project. This was one way to develop local capacities which is an important development norm for the less developed countries. Involvement of local and sanitation, WHO - health, UNOCHA demining, WFP - food and shelter programme, UNESCO - education, FAOagricultural development and UNDP coordination. In addition a number of NGOs were involved as implementing partners.

authorities was another aspect of this programme which enabled sharing of responsibility with local shuras (councils) making them partners of this integrated exercise. Sustainability of the programme is thus automatically assured. 


\section{Participatory approaches}

An important aspect that has been added to this integrated project of UNHCR was the opportunities provided for the refugees themselves to participate in the process of implementation. This seems to be the vital element in this model providing for genuine participation of the returnees in development. They were involved both in the identifying of needs, as well as in the implementation of the projects.

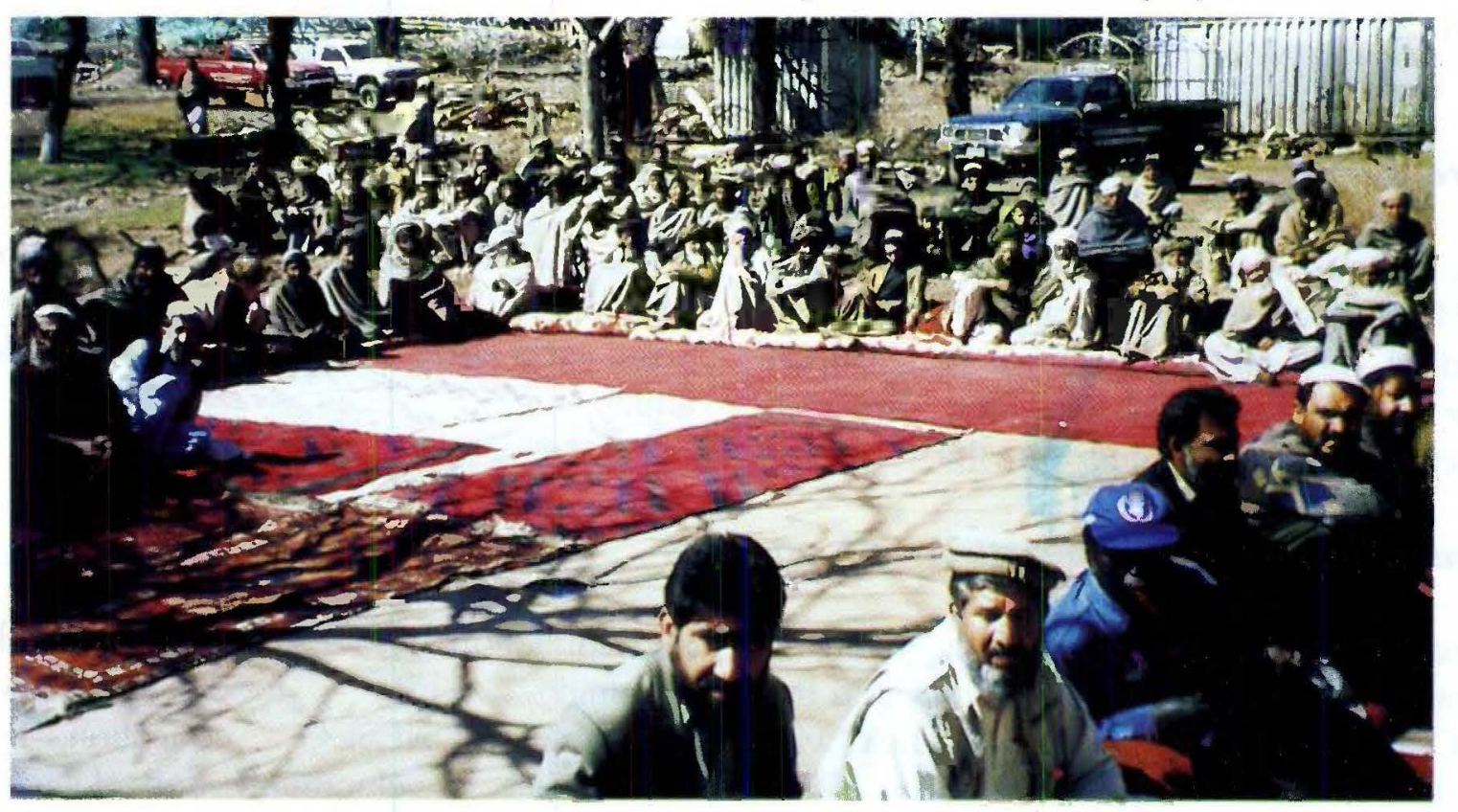

Discussion with the community of elders - Tezin

\section{Imposition of a full family unit /motivational demands}

In order to encourage to return of the whole family, it was made compulsory that all entitlements, both financial and material, would be provided only to those who bring the full family and not just part of it. Those who return only partially to their place of origin are not entitled to UNHCR shelter assistance.

\section{Payments for the shelter programme}

This was to ensure that a proper evaluation of the houses was made before payments were meted out. A team from UNHCR did this using the criteria of the nature of destruction. Thus if a family has an undestroyed house with more than the living area, that family will not be 
eligible for assistance. However, if the existing living area is less than the space stipulated by this project such families will be provided assistance.

It was expected from the returnees that they would expand their living area slowly themselves by using their own resources. All those whose houses have been completely destroyed are eligible for the full assistance in reconstruction.

\section{Food for work}

Using food for development purposes has been a common feature in all the developing countries. The same principle was adopted in this project too. Wheat flour provided by WFP was distributed bi-weekly in accordance with their attendance. As food was an important item, the distribution was carefully monitored by implementing partners. Food was linked only to manual work, for those who were involved in the rehabilitation and construction of their dwellings.

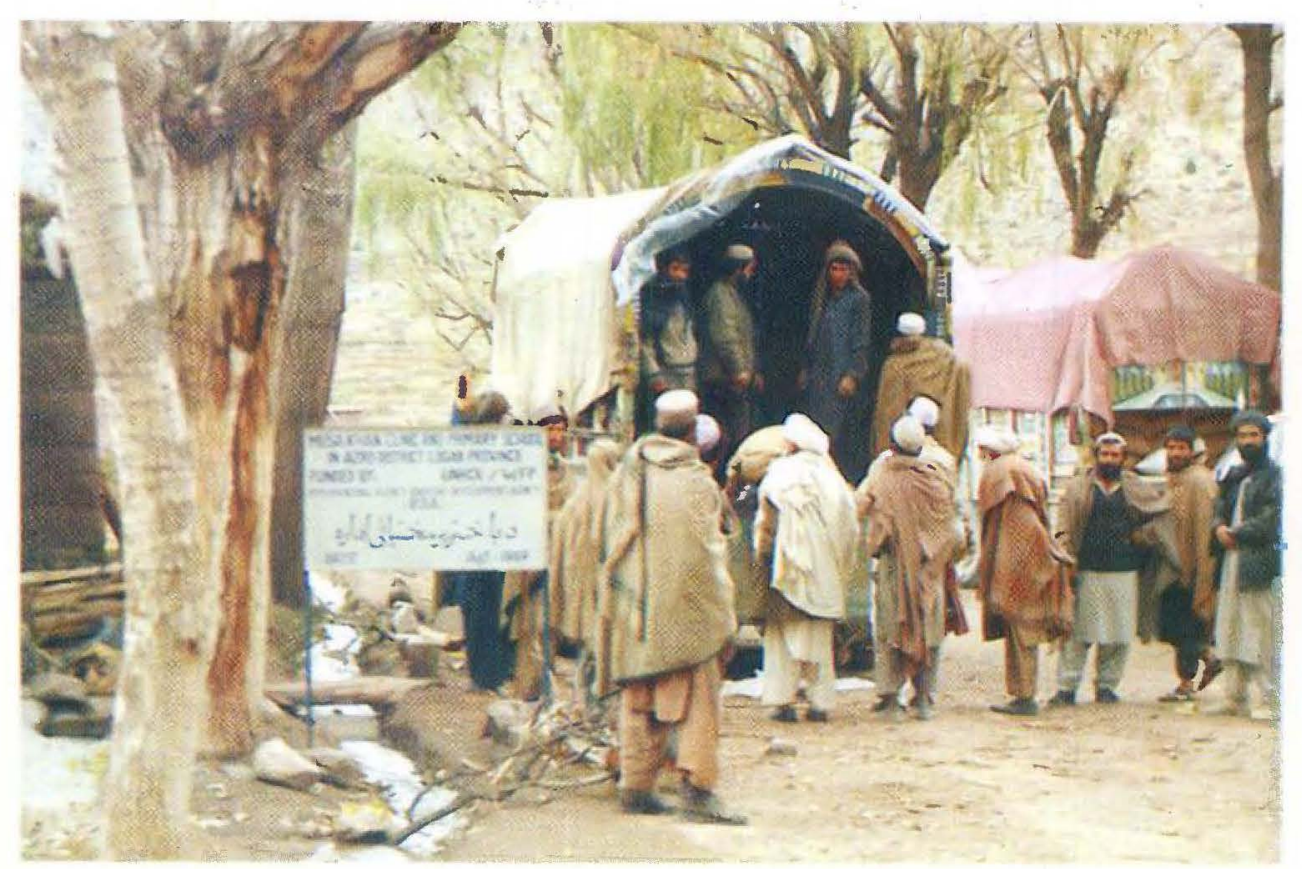

People receiving food from WFP

\section{Facilitating registration}

In order to facilitate the process of verification for the returnees, a number of reception points were established for both registration and encashment. The registration included the names and addresses of the returnee families which were later sent to respective UNHCR offices. Before the returnees got back to their place of origin, representatives of the local authorities and UNHCR officials would meet them at their respective places of residence. 


\section{Monitoring}

The construction of the houses comes under the supervision of UNHCR and its implementing partners. The returnees are expected to complete the construction within two months of arrival. The principle of selfhelp is incorporated into this programme.

The materials needed for the construction are obtained locally. The local shuras and the local authorities are also partners in the monitoring process. This makes the latter group very cooperative. They are also involved in meetings held monthly to discuss the progress of work. The responsibility of the team is related to the following areas:

- assuring the provision of assistance to the identified beneficiaries as approved in the document

- seeing to the recording of assistance by the implementing partner
- scrutiny of both the quality and quantity of the construction materials distributed by the implementing partner to the beneficiaries

- assuring food from WFP is utilised correctly

- supervision of the minimum required number of households $(20 \%)$ and recording their concerns

- reporting the progress of the above areas to UNHCR and WFP, including suggestions for improvements

To ensure that progress is carried out according to accepted guidelines, crosschecking via distribution monitoring and evaluation by senior officers of both UNHCR and WFP has been included. Thus as part of this exercise the visits to the sites of these senior officers take place during and after the distribution.

\section{Participatory Nature of l'e Antivities}

It is a unique exercise where all actors are consulted in identifying and designing the activities and a consensus is arrived at before proceeding for implementation. The actors includes UN agencies, returnees, the existing population of the district through the shura and the district and provincial authorities, specialised NGOs, and the Japanese counterparts in Islamabad. 
The process also followed closely the principles of the PEACE initiative carried out by UNDP in 23 districts of Afghanistan.

Using the above principles and modalities, a number of initiatives have been undertaken under the integrated project of Azra and Tezin. These included the following:

\section{Provision of safe drinking water - basis for healthy living}

The basic cause for most diseases is a poor water supply. Many streams in the area run dry during certain periods. Thus the issues relate not only to availability of water but access to clean and pure water, which is available in abundance in the mountain springs of these two districts. Under this activity it is planned to harness this natural resource by providing a gravity-fed drinking system for 15 villages, as well as 70 deepwell hand pumps in 16 villages, costing a total of US\$130,951 from UNHCR and the food-for-work programme of WFP.

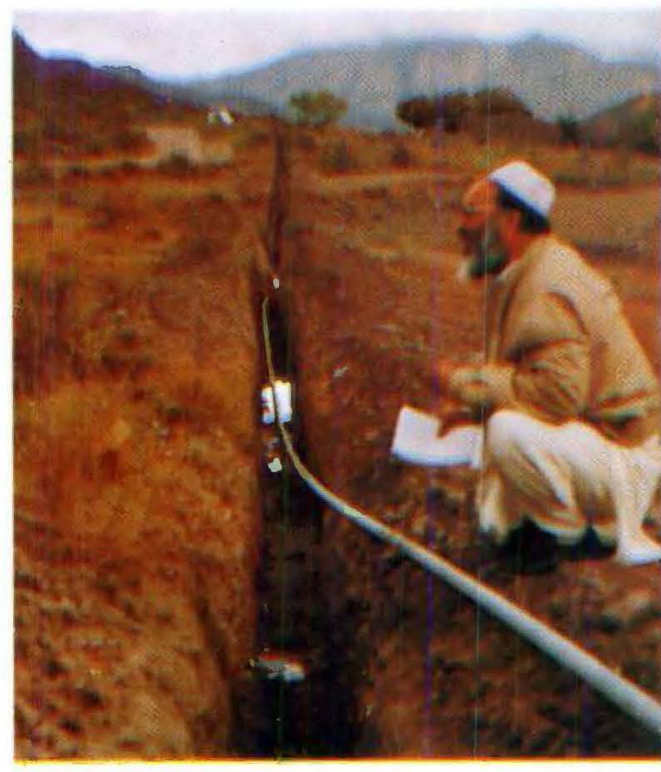

Laying pipeline in Azara

The facilities developed for this purpose are to be handed over to the local authorities for sustainability and continuity. It is expected that UNHCR would provide the running costs of this activity for some time to come. The water project was completed in

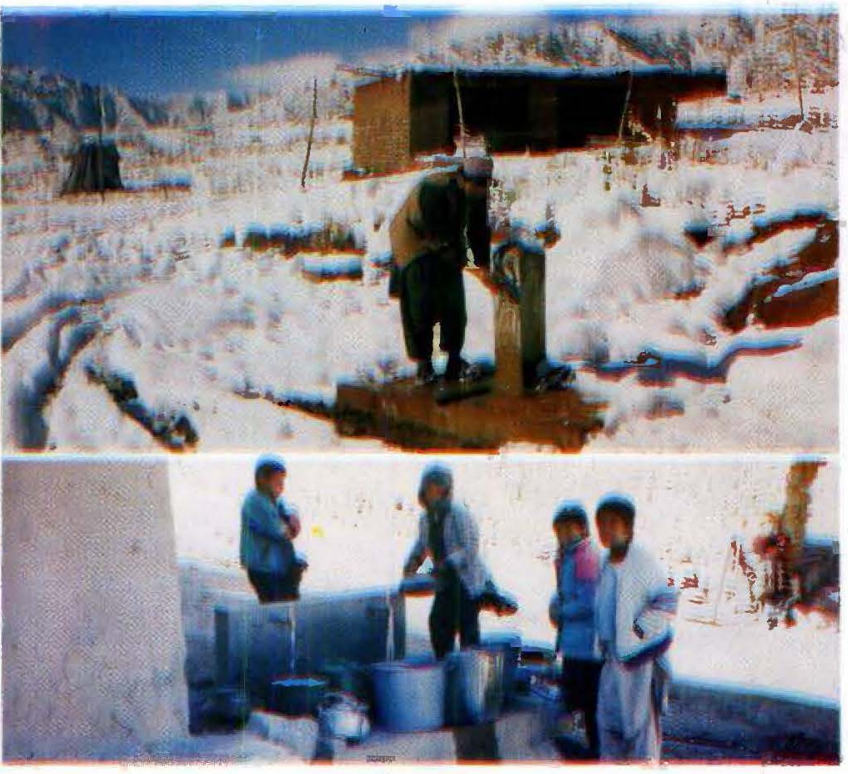

\section{Joyful beneficiaries}

five months by young Afghan engineers who piped a spring water reservoir to 35 outlets in the villages. It has been designed to meet the needs of at least 24,000 people for some three decades.

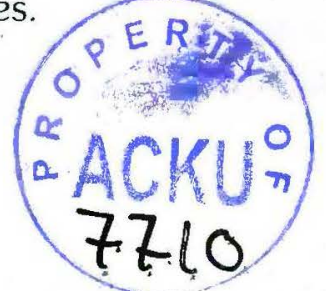




\section{Demining}

Mines have caused terrible injuries to both young and old, often leading to the loss of limbs and sometimes of lives. Afghanistan is one of the most heavily mined countries in the world today. The most vulnerable are the children. Hence demining could be considered the most important initial step in a rehabilitation programme in Afghanistan. Although, demining is an on-going activity, certain stretchers of the road to Azra/Tezin are not mine free. These have to be cleared.

\section{Passage to Azra/Tezin}

Accessibility to these areas is one of the important needs in order to facilitate movement of people and materials. Subsequent economic revival and development in commerce and trade will require a good network of roads. This is vital for returnees who are used to better communication facilities and are also well articulated in commercial enterprises in Pakistan.

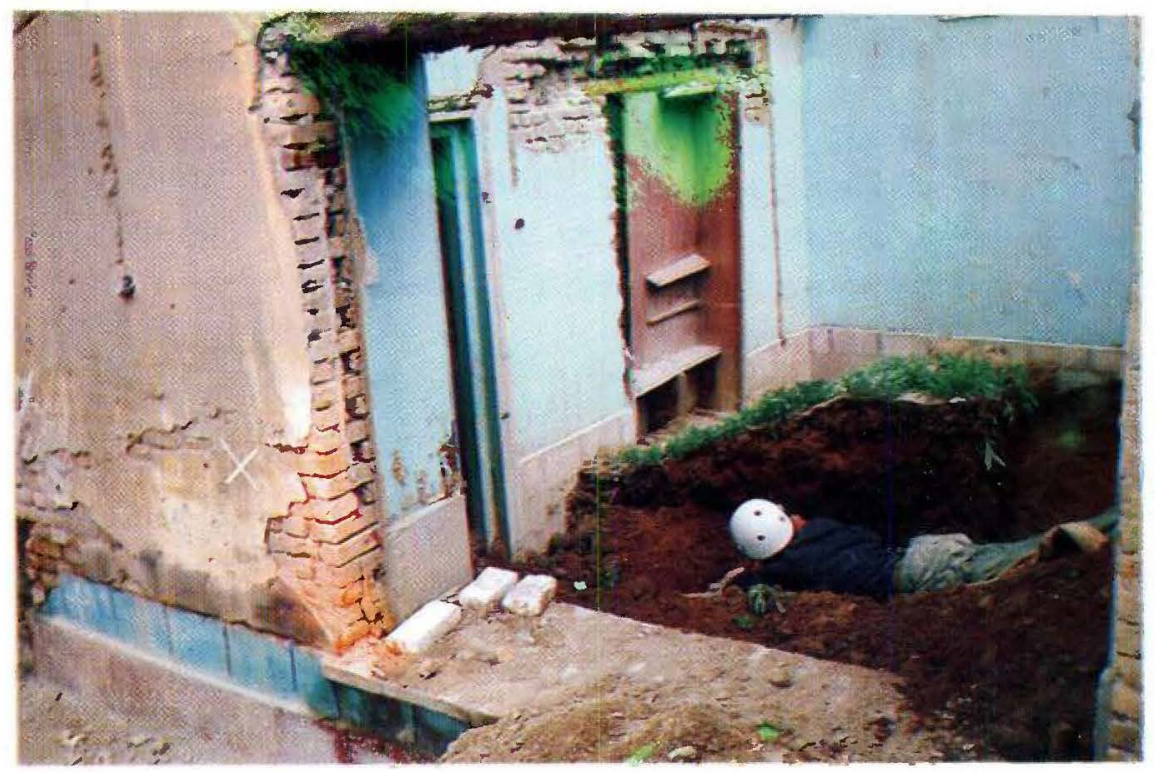

Making homes safe from mines

As it is, getting to Azra and Tezin not only takes many hours but involves crossing extremely difficult terrain. The river beds form the road in some areas and in winter all road communication is cut off for nearly 6 months of the year. The existing roads to Azra are from Jalalabad $(120 \mathrm{~km})$ and Pul-e-Alam $(140 \mathrm{~km})$. Since repatriation takes place mainly through Jalalabad, the road to Jalalabad has to be strengthened and rehabilitated. Likewise, the rehabilitation of the secondary roads inside the districts, as well as the canals, flood protection walls, and similar protective precautions have to be taken as a priority in order to support the stability of the road. The rehabilitation of this road stretch includes side ditching, gravelling, construction of culverts, fords and retaining walls. However for the time being only the major damages and needs are catered for in the planned activities. In this matter UNOPS has already carried out feasibility studies under the PEACE programme of UNDP. 


\section{Roofs}

As thousands of refugees are expected to return to Azra and Tezin in the near future they should be assured a stable roof over their heads. Most of the houses left by the refugees almost two decades ago are completely destroyed and the poverty of many of these returnees would not permit them to reconstruct their houses on their own without assistance. If this need is not supported the whole repatriation programme will be jeopardised. Hence UNHCR has designed a Shelter Programme to assist the neediest returnee families. They were provided with basic shelter materials which they would not have been able to procure themselves. The experiences of two previous projects on shelter designed by UNHCR in the province of Logar were made use of in the planning of this programme for Azra and Tezin with minimum changes. The modalities of this programme were as follows:
a. direct participation of returnees in the implementation of the project
b. participation and involvement of the local authorities in the implementation of the project
c. maximum use of the existing. local resources through local bidding system and collaborating with local authorities
d. introduction of effective methods of project implementation
e. collaboration with the World Food Programme over food for work.

\section{Human resources development / education for all}

Negligence of education in Afghanistan has led to a lack of self-confidence in the community, aggravating the dependency syndrome that has already set in the country. Under such circumstances where the current level of education of the people is very low, issues related to access and equity are complex and the capacity for human resource development is marginal, the prospects of the future development of Afghanistan are bleak. In the development paradigms no country in the world has risen beyond the level of education.

All these problems call for multiple motivational strategies. One way would be to provide access to education for all, without discrimination, through a multiple entry and exit system. Providing facilities for education and others services to match the basic needs would be another important step to encourage them to return to their places of origin.

As education, along with security and community mobilisation are the main areas of concern of the returnees, UNHCR collaborated with UNESCO to develop an educational development programme for these two districts. It was also pointed out by UNHCR that the educational 
needs of the returnees may be different as they had been exposed to a better system of education while in exile. With this in view UNHCR focussed on the following aspects, for the consideration of UNESCO:

a. Identifying the educational needs of the returnees

b. Identifying the material needs of the schools

c. assessing the professional needs of the educational personnel

d. assessing the needs of the young and of women in relation to basic education.
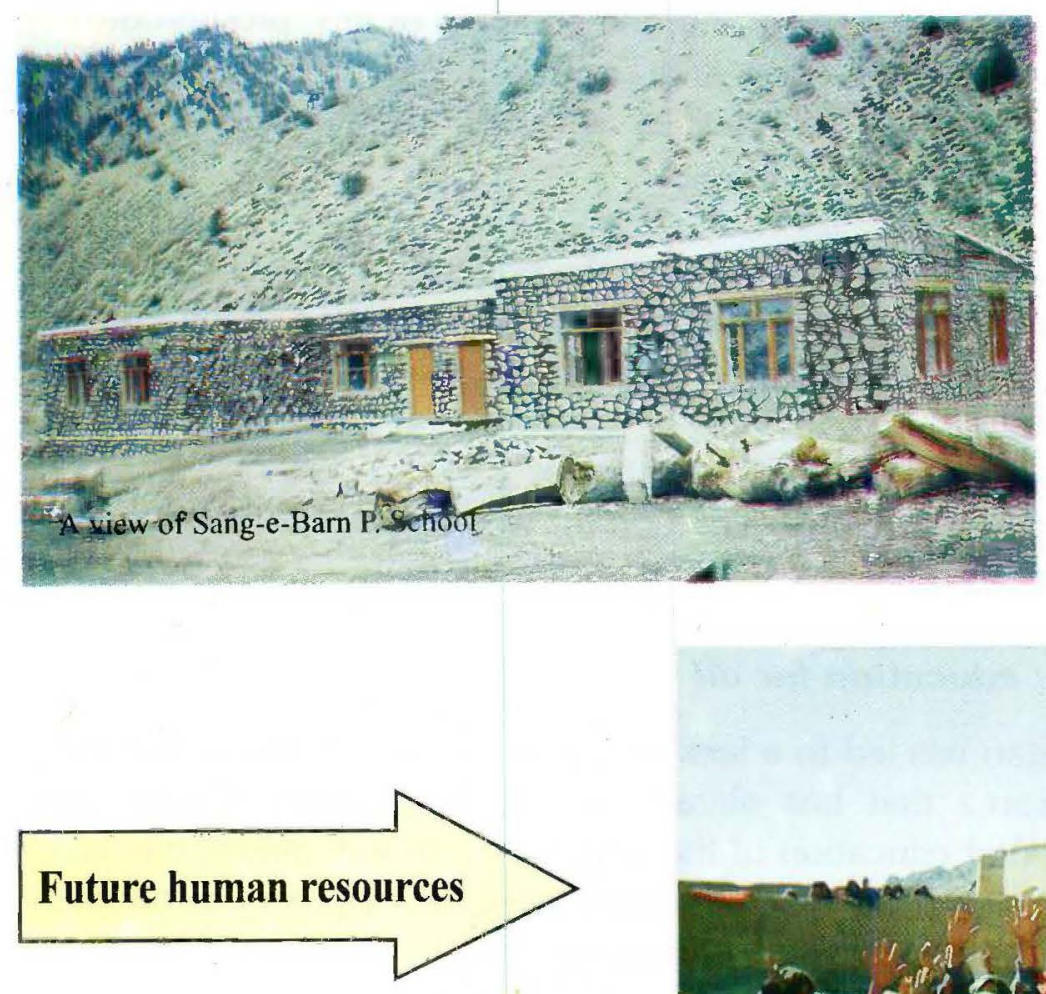

\section{Community assurances}

Key needs of the returnees

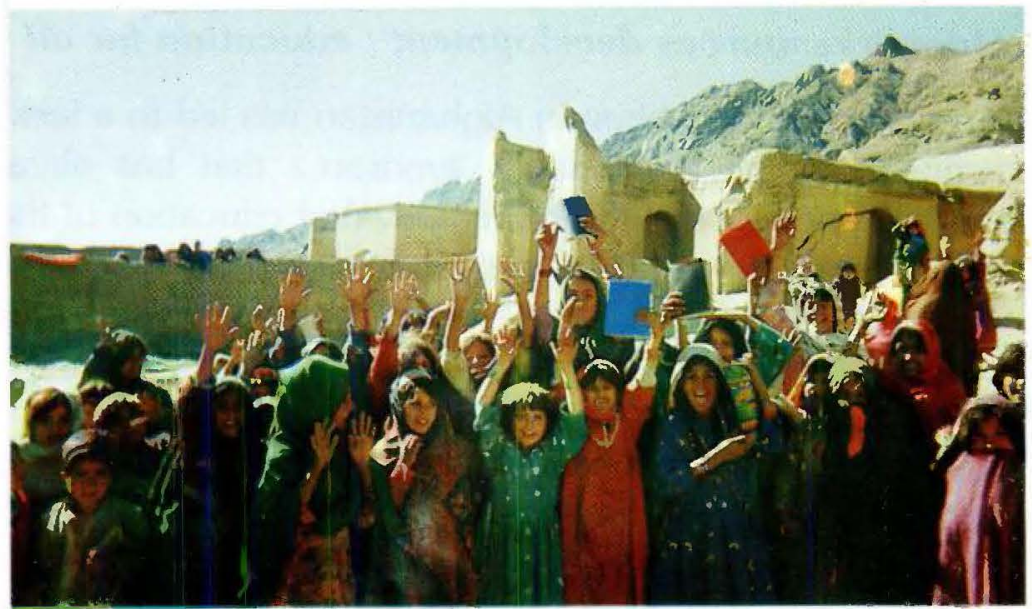

Future human resources

In the discussions between UNESCO and the elders of Azra, education was indicated as one of their key needs and this they felt should be provided to the returnees in keeping with the standards they had experienced in Pakistan. All the village elders were unanimous that 
education should be provided to both boys and girls and when the necessary provisions are made they would return to Azra and Tezin without any delay. They also suggested that it is desirable to have separate sessions for girls and boys in the schools.

\section{Teachers from the locality}

The members of the community also stated that they could provide teachers from their locality who could be considered for appointment. This was very important since it would be very difficult to find teachers from elsewhere to serve in these areas, especially women. It indicated the desire and the commitment for education of the returnees, and those of the people living in these districts, who have had no access to learning for over a generation.

Initial phase of the establishment of schools

\begin{tabular}{|lccc|}
\hline & Primary & Secondary & Students \\
\hline Azra & 04 & 02 & 1000 \\
\hline & & & \\
\hline Tezin & 01 & - & 400 \\
\hline & & & \\
\hline Total : & 05 & 02 & 1400 \\
\hline
\end{tabular}

\section{Material needs for learning}

\section{- text books}

Arrangements have been made to provide text books numbering around 20,000, for all students in all grades in these schools. These text books developed by an NGO are the ones that are widely used inside Afghanistan as well as in the refugee camp schools in Pakistan. To avoid any delays in the supply

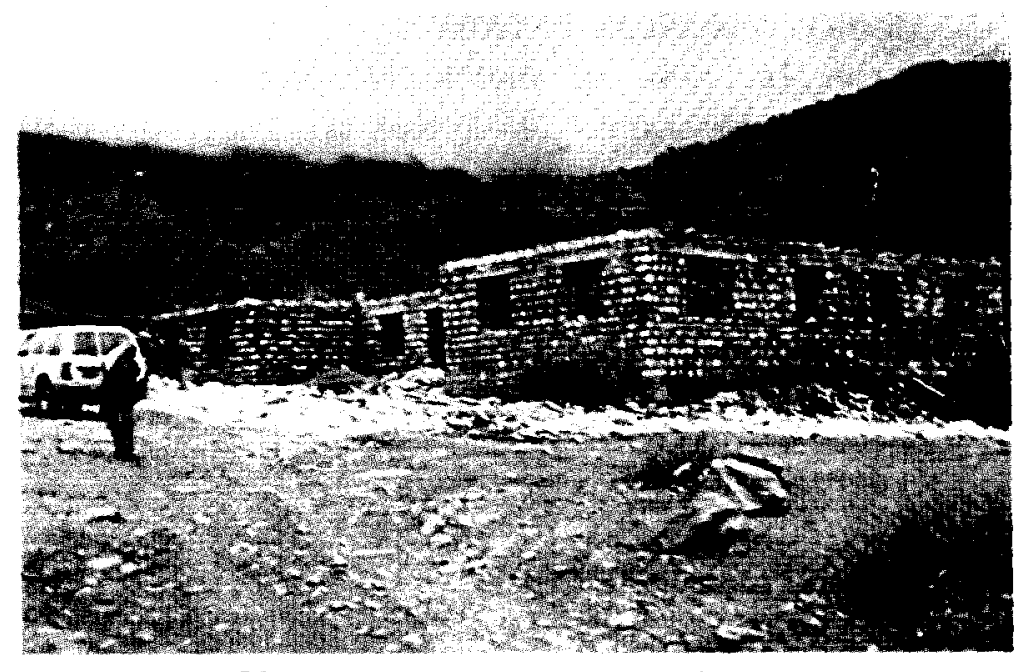

Mangal primary school - Azra

of text books in the future, texts for grades 1 8 are printed already, although the current need is only for grades 1-6. Further, additional copies of all these are printed in order to cater to additional numbers that may increase in the future. 


\section{- school materials}

All materials needed for the schools such as blackboards, chalk, stationery, furniture, plastic carpets etc. are to be supplied for all the schools.

\section{Professional development/capacity building of educational personnel}

\section{- teachers/principals}

It is well known that all needs of the schools in developing countries cannot be fully provided. A well trained teacher/principal would be able to substitute for many shortcomings in materials and other needs and fill the gaps successfully. Thus in Afghanistan, and specially in these iwo districts, the ideals in terms of materials will never be able to match the needs for decades to come. This was the view of UNESCO and suitable measurers are being taken to improve the capacity of the teachers as well as provide for the basic needs of the schools.

\section{- principals/supervisors}

As the management capacity of the principals has to be strengthened and assured in contextual issues a guide book on - Management of primary schools under

\section{- training programmes}

Training programmes for both teachers and principals have been arranged in collaboration with UNESCO and an NGO namely Solidarite Afghanistan, Belgium.
As the teachers appointed from the locality are very likely to be untrained, lacking exposure to pedagogical skills. UNHCR has developed a 'Guide book for the teachers'. based on the above text books. This guide book provides assistance to all teachers in all grades.

In addition a 'Hand book on multi-grade teaching', developed by UNESCO is also made available for these teachers.

stress' specially designed and developed by UNESCO in Afghan contexts is provided for all the principals and supervisors.

The training will be focussed on the needs of the teachers in Azra and Tezin. Already a handbook titled "Issue focussed teacher education: Handbook for teacher educators 
in Afghanistan" has been developed by UNHCR in collaboration with UNOPS and an NGO, namely Swedish Committee for Afghanistan. This book is to be provided to

\section{Approval by local authorities}

Since education and the materials are very sensitive issues, UNHCR took the initiative to seek approval for all text books and resource materials for teachers and principals prior to all teachers and teacher trainers. This book focuses on the socio-psychological aspects of the traumatic child.

printing of the materials. This was considered an important step to bring about an acceptable and cooperative relationship with the local authorities.

\section{- health facilities}

In collaboration with $\mathrm{WHO}$ and WFP, UNHCR has opened up clinics. The Ministry of Health was associated with the programme from the planning stage. Besides regular delivery of medical services through clinics, special provision for the delivery of health services on TB and polio have been organised both in Azra and Tezin. The organisation of such services will cover both curative and preventive services through both fieldextensive and clinic based services. Immunization services will be provided with particular emphasis on polio eradication. WHO will coordinate with UNICEF regarding regular supplies of vaccines/equipment and other support following their standard EPI strategy for Afghanistan.

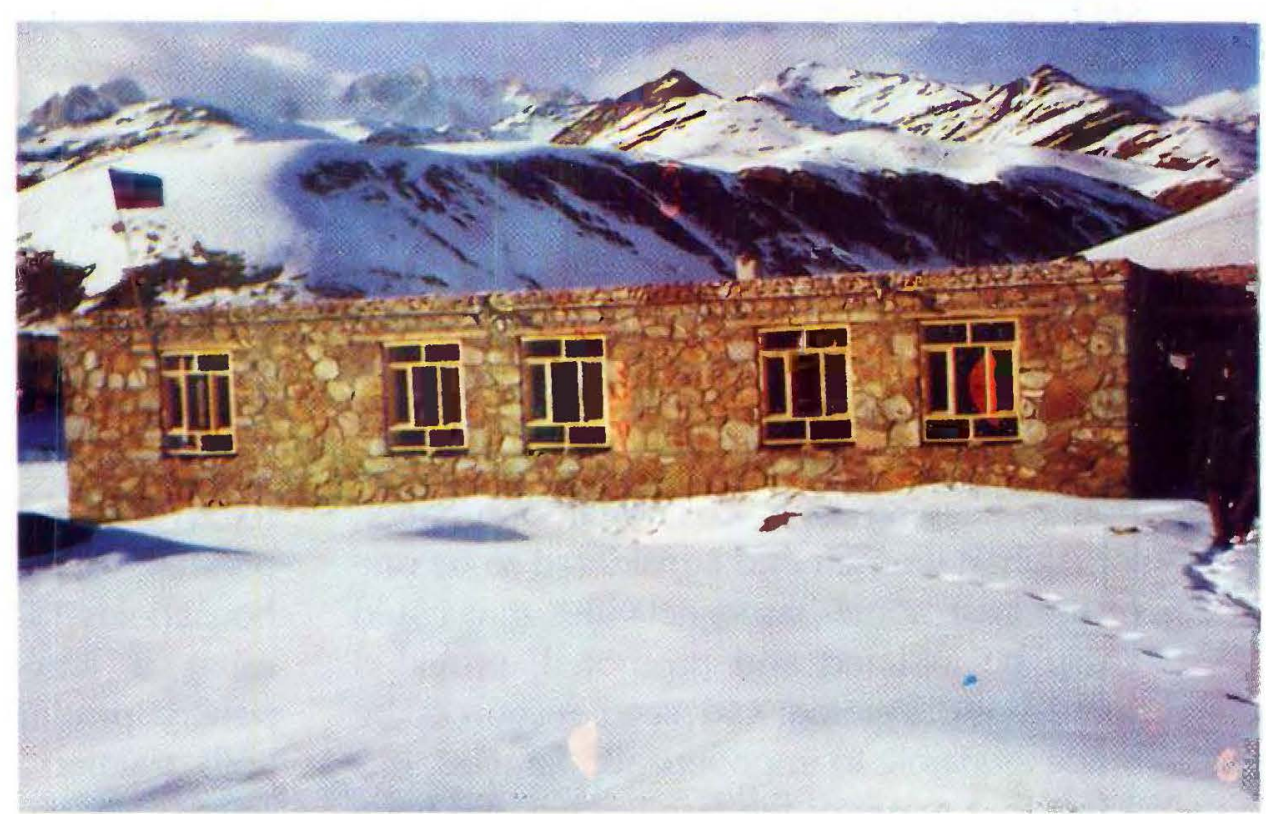

Sang-e-Baran clinic for returnees

About 60 per cent of the budget will be spent on TB control. 
The project supports an integrated health care systern in line with the framework of primary health care strategy in Afghanistan with particular emphasis on sustainability and community-based approach.

In addition to the establishment of clinics, the concept of building on what was existing has been emphasized. Local health care

\section{- revolving fund}

In order to facilitate the income generating activities of both men and women, some funds for home-based economic activities in assisting the poorer segments of the returnees have been planned. The estimated number of those who would need such assistance is estimated to be around 2000 families in both Azra (1500) and Tezin (500). Here too, previous experiences of UNHCR efforts in Kabul are replicated. workers will be trained and community health education will be prioritized.

Health supporting agencies like WHO and UNICEF will provide their support through the local health authorities. Similarly the project aims to strengthen the local capacity through in-service training, and basic supplies.

However modifications have been made for rural contexts in these two areas. WFP is providing support to these programmes as well. This is to ensure that the returnees who are involved in home-based economic activities do not use the revolving funds for their day-to-day expenses. The participants in this programme will receive WFP assistance for a period of up to six months.

\section{Home-based and community-based economic activities}

\section{Poultry production}

Poultry-keeping is a traditional occupation for Afghan women and considered to be one of the best home-based activities that could easily be initiated and promoted, provided some basic training and seed resources be made available to impoverished families. It is a fact that many of the families will not have enough land to work and earn their livelihood in Azra and Tezin when they return back home. In this respect a poultry project has been designed for 450 households (300 in Azra and 150 in Tezin) using a kerosene-operated incubator for poultry production. The project will have both training and production components. There will be three or more training sites according to requirements. Primarily the women will be encouraged and targeted to 
participate in the training. However, depending upon the prevailing situation, male participation as an option will not be discarded or discouraged. The project is seen

\section{Community fishery}

Considering the availability of agricultural land versus the expected scale of population returnees to their places of origin, Azra is more vulnerable than Tezin. It is obvious that there is and will be a shortage in sources of food/protein in both Azra and Tezin. An alternate possibility is a plan for $a$ community-based fishery in Azra. While proposing a community fishery, the geographic features of the district has been taken into consideration. The construction of infrastructure for one small scale community

\section{Agricultural and related inputs}

It is believed that several kinds of agricultural inputs would be required for longer-term sustainability of the returnees for which a greater amount of development investment will be required. In this respect, only a provision of funds for immediate and prioritized interventions has been proposed.

\section{Seed and fertilizer}

Quality seed offers great potential for the reintegration of returnee farmers. Considering the fact that seed supplied with matching quantities of DAP and Urea fertilizers could ensure remunerative return as an alternate self-reliant scheme for those desperate returnee families who have minimal land holdings or have no lands at all.

fishery project at strategic locations in Azra has been studied and proposed on a pilot basis. The operational modality and initial seed inputs for operation have been calculated at the rate of $10 \%$ of the total cost. The training, organization and community management of the fishery are still to be discussed with concerned agencies and the community. A specific implementation procedure will be workedout later considering the longer term sustainability of the project.

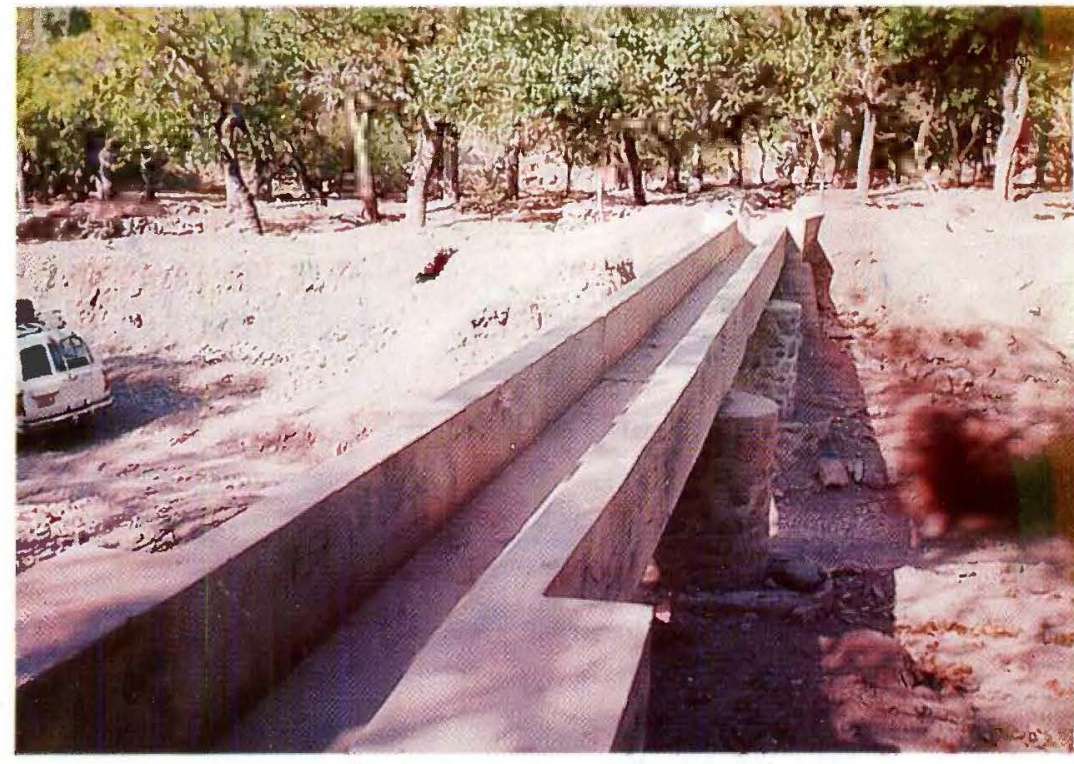

Flume of Sorey Kaga Canal - Tezin 
to returnee families, a provision has been made to cater for the neediest 800 families. It is proposed to make available at least 200 MT seed and equal quantities of DAP and Urea fertilizer for distribution among at least 800 farming families $(250 \mathrm{~kg}$ of seed for each family). The recipients of seed will be encouraged to retain part of the produce as seed for next year so that they need not

\section{Community based nurseries:}

Considering that many parts of the district are good for horticulture and also the fact that deforestation is an extreme problem in the area, provision for the establishment of four community based nurseries (three in Azra and one in Tezin) for the promotion of horticulture and afforestation has been encouraged. Since there is no technical depend on outside sources for the next 2-3 years. FAO will make the necessary arrangements to produce the seed and to train the recipient farmers on farm seed production techniques. All details of the project will be finalized with FAO.

assistance programme available in the district with regards for horticulture and agriculture, the provision of such technical assistance would be made through appropriate coordination with FAO. Details of this programme of activities will be finalized with FAO.

\section{istis}

\section{Task-oriented Missions}

It is interesting to read the comments, taken verbatim from the field reports of the missions undertaken by field officers of FAO. The objective of one of these missions had been to evaluate ongoing and completed irrigation sub-projects in Azra and Tezin. The observations and suggestions made by the Field Officer state: "in the irrigation sector generally it needs to decrease the cost per hectare and increase the land to be served." Further the report states that "road repair is still a priority for Azra and Tenzin. The roads sould be repaired according to the acceptable engineering standards". In relation to irrigation the same report says that "one of the very valuable and useful works in Azra and Tezin were water channelisation and de- silting projects which 
were appreciated by the local people and they request for more and more work in different places. Now in this area, agricultural land is safe enough against further erosion and flood damage... and complete assurance also for the villages and houses on both sides of the wash ... and the returnees are rebuilding their houses in this area, where before they could not do so because of flood danger. The construction work of all of the above mentioned subprojects was very good, the quality of material used in the structures was very high and monitoring during and after implementation was very serious with concrete decisions". These reports also reveal that comments / observations of previous reports are followed up carefully and meticulously. Thus "the reporter saw the changes in the design of the structures built on the canal (Barber canal rehabilitation) that were suggested in the previous mission report". This project also had in-built components for the capacity building of the farmers which included "proposals on farm water management course for farmers in Azra and Tezin which could not be held due to the current circumstances".

\section{Coordination}

To facilitate cooperation and collaboration between the different UN agencies and implementing agencies/NGOs participating in the joint UN programme for repatriation and reintegration, a Programme Coordinator
(PC) was appointed. The PC works as a member of the common UN programme and coordination team connected to the office of the UNDP Representative and the UN Coordinator for Afghanistan.

\section{Establishment of an inter-agency secretariat}

The Programme Coordinator has established a secretariat to support the activities of the joint programme. He convenes and chairs regular inter-agency meetings, at the operational and management levels and at the district, regional and national levels, to review and analyse progress and plans and to facilitate discussions and agreements on key issues. 


\section{Monitoring}

The PC monitors implementation of activities through periodic field visits to assess progress and impact of the

\section{Reporting}

This is another responsibility of the PC. The PC gathers information and prepares programme progress reports every two months and circulates to all agencies

\section{Principled approach}

The PC supports, monitors and assesses the use of the operational guidelines on a principle-centered approach in support of the UN gender policy for working in Afghanistan.

It is recommended that funds for implementation of sectoral components be directly earmarked and channeled to the relevant agencies. It is believed that this arrangement will greatly facilitate the reporting, evaluation and accountability process. programme and makes relevant recommendations to the agencies concerned. concerned and also provides regular reports to donors and facilitates donor missions to the programme areas.
UNCHR has given due recognition for the Japanese funds through project bill boards, meetings with the beneficiary communities and authorities, UNHCR publications in the field and at the Headquarters levels as and when appropriate.

The budget to be earmarked for the salary benefits, vehicle, vehicle running cost and two national support staff for the Coordinating Officer by the Government of Japan is estimated at US $\$ 200,000$.

\section{"It is in the minds of men that the defences of peace must be constructed"}




\section{Conclusions and Lessons Learnt}

- This is an innovation in context. Innovation is an approach where you look at an issue which has not been solved in a new way and work a way out of it relatively successfully. Azra/Tezin project represents an innovative approach to solve the complex web of problems having a large community of returnees. Without such an approach, the number of returnees would very likely remain extremely limited. The process involves viewing the issue from different dimensions to evolve possible solutions. The core message of this type of innovation is empowerment and change. It has characteristics of flexibility in methods and processes, multiplier effects and capacity for adaptability. Innovations should be responsive to the needs of the community. Therefore innovations should a) address the needs and problems unsolved by conventional practices b) strengthen the capacity of beneficiaries to improve their quality of life c) find solutions which are successful, desirable, effective, efficient and sustainable over a period of time.

Therefore innovations such as Azra/Tezin project are risks because they do not follow the trodden path The significance of innovative efforts relate to adopting measures that have been there but no one had identified before.

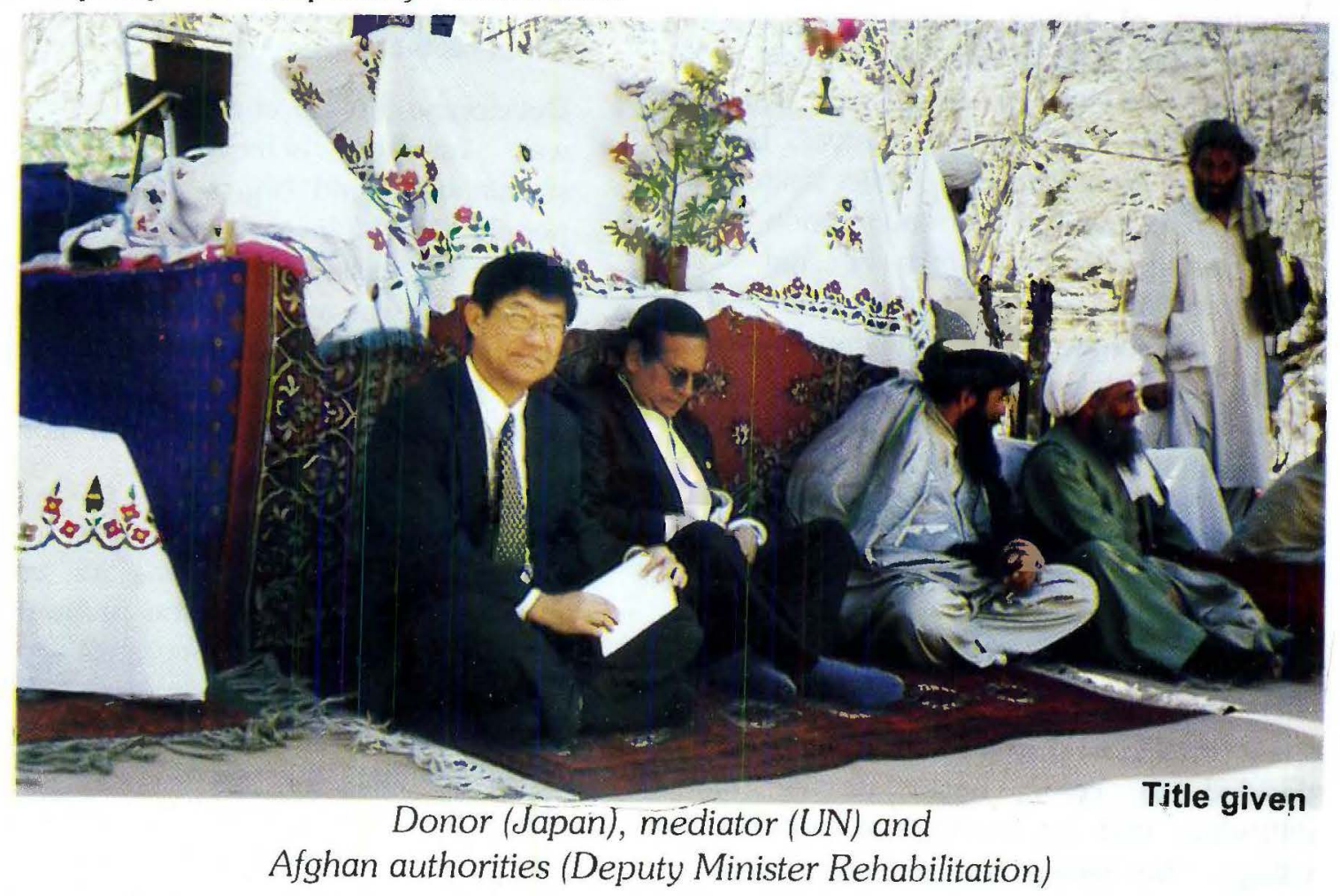


Viewed from the above, one could perhaps call the project conceived by UNHCR in Azra and Tezin "an innovation in context". The integrated approach brought many partners together which included the beneficiaries, local authorities, the grassroots level implementers (NGOs), the middlemen (UN agencies) and the donor (Japanese government). It helped to bring about coordination to achieve a common target. Furthermore, the approach enabled integration amongst disciplines.

- UNHCR focussed on an area which is very difficult to access. Experience gained by working out a project in such a difficult scenario should provide additional skills in the operations of future programmes of this nature. They help to develop a model to be replicated elsewhere in Afghanistan. This was supported by Mullah Rehamatyar, Deputy Minister of Rehabilitation, while visiting the area to participate in the inauguration of the water project in Azra when he said "we assure you after all the sacrifices they gave to defeat the biggest evil on earth". The UNHCR officials were full of praise for Rehamatiyar's cooperation with the organisation. According to Nabil Makki, Head of UNHCR sub office Jalalabad, "the foremost consideration for the selection of this area was the willingness among the locals to return. It was they who sought our help so we know that they meant business". One such person was Dr. Gul Zalamy, who had spent years in a refugee camp in Pakistan and decided to come back, despite many difficulties that he would face back in his village. "We belong here and this where we should be", said Zalamy and hoped that many more of his countrymen would return back to Afghanistan

- Providing confidence to the stakeholders is another innovative practice that pervades this project. The people of Azra and Tezin were involved in every aspect of the development process which made them confident and aware of what they were going to receive. This forms a key element in the culture of development in the developing countries. This was clearly demonstrated when Salam Gul, returned home to Azra last year with his five children to a demolished ancestral home and fields full of wild bush. "I decided to come back with my children because I thought that 14 years of refuge in life was more than enough. Someone has to come back and start rebuilding" said Gul while planting almond saplings. He felt secure to go about his business.

- Developing the self confidence of the people was another achievement. It assists sustainability and brings about the best in people. Use of local resources was one way. Using the village elders as partners in monitoring was another approach. Adopting acceptable measures to provide more to those who have less and thus achieving equity. provided the beneficiaries with confidence and faith in the implementers.

- Involving the donor directly in the implementation process was an important step which encouraged the partners in the exercis. Hiroyasu Kobyashi, second in command of the Japanese embassy, Islamabad was clear about this when he said while attending the ceremony to inaugurate the project in Azra that "We believe that we don't have necessarily to think the way some European countries do when it comes to 
dealing with the areas under Taliban control or the whole issue of rehabilitation". It indicated the need for flexibility in the approaches to assistance for a devastated country like Afghanistan. Appointment of a coordinator to monitor the project for the donor enabled close monitoring of the project for progress.

- Attempting to provide most of the services that the returnees enjoyed in Pakistan was a welcome measure. The fact that most of the returnees were coming home after a lapse of nearly 20 years, having enjoyed better facilities while in exile had to be understood and suitable provisions to meet some of those facilities had to be made. The integrated approach of this project had that vision.

- Bringing to light the importance of 'endogerity' in development is another achievement of this project. Endogenity means 'growing within'. It means the internal process of reflection and creation. Endogenity in development cannot be achieved without participation of the people involved. The people have to articulate the specifics of the situation, and the needs to be met and prioritise them. Participation in this project was not manipulated but was autonomous and informal.

- Innovations invariably have elements of risk. This project is no exception. Since the project is still in its infancy and working under arduous conditions, politically as well as physically, the progress of the project has to be analysed from these contexts. Yushi Yamamoto, Coordinator of this project was very pertinent in this respect when he said that "In the beginning, it looked awkward. But now it could hardly be imagined that a UN agency works alone in the field. It seems that inefficiency and ineffectiveness would be unavoidable unless such a coordinated/integrated approach is adopted. Despite all obstacles, I feel that this approach will be the norm in the future development programmes of the UN".

\section{Transparency and Mid-Course Corrections}

\section{Practical issues for the future}

At a speial meeting held to review the progress of the activities to facilitate mid-course corrections, the following were brought to light. The donor - Japan, the UN Coordinator and the representatives of the UN agencies, were present at this meeting. It was pointed out that :

- in project formulation more attention should be paid to gathering baseline data particularly on population 
- Afghan knowledge should be used more effectively

- the final conclusions of the project should not be arrived at the end of one year since some activities are still ongoing

- the medium term and long term needs to be looked into in relation to sustainability which demands more Afghan participation and less reliance on external factors

- the delays in achievements in certain sectors need precise explanation

- the importance of participation of the field staff at the planning stages

- more authority should be delegated to the field staff for better implementation

- joint assessment by agencies to bring about a consolidated plan is vital

- similar exercises on the Azra/Tezin model should be developed

For the first time new dimensions were brought into the donor/agency

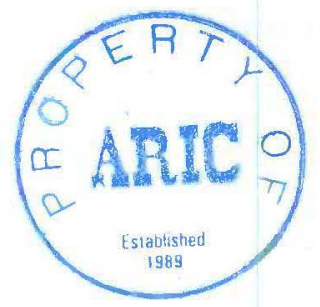

relationships in this model project. These were very healthy, resourceful and empathetic in nature. It increased openness, honesty and transparency between and among the partners adding a new page to the development paradigms in the developing world.

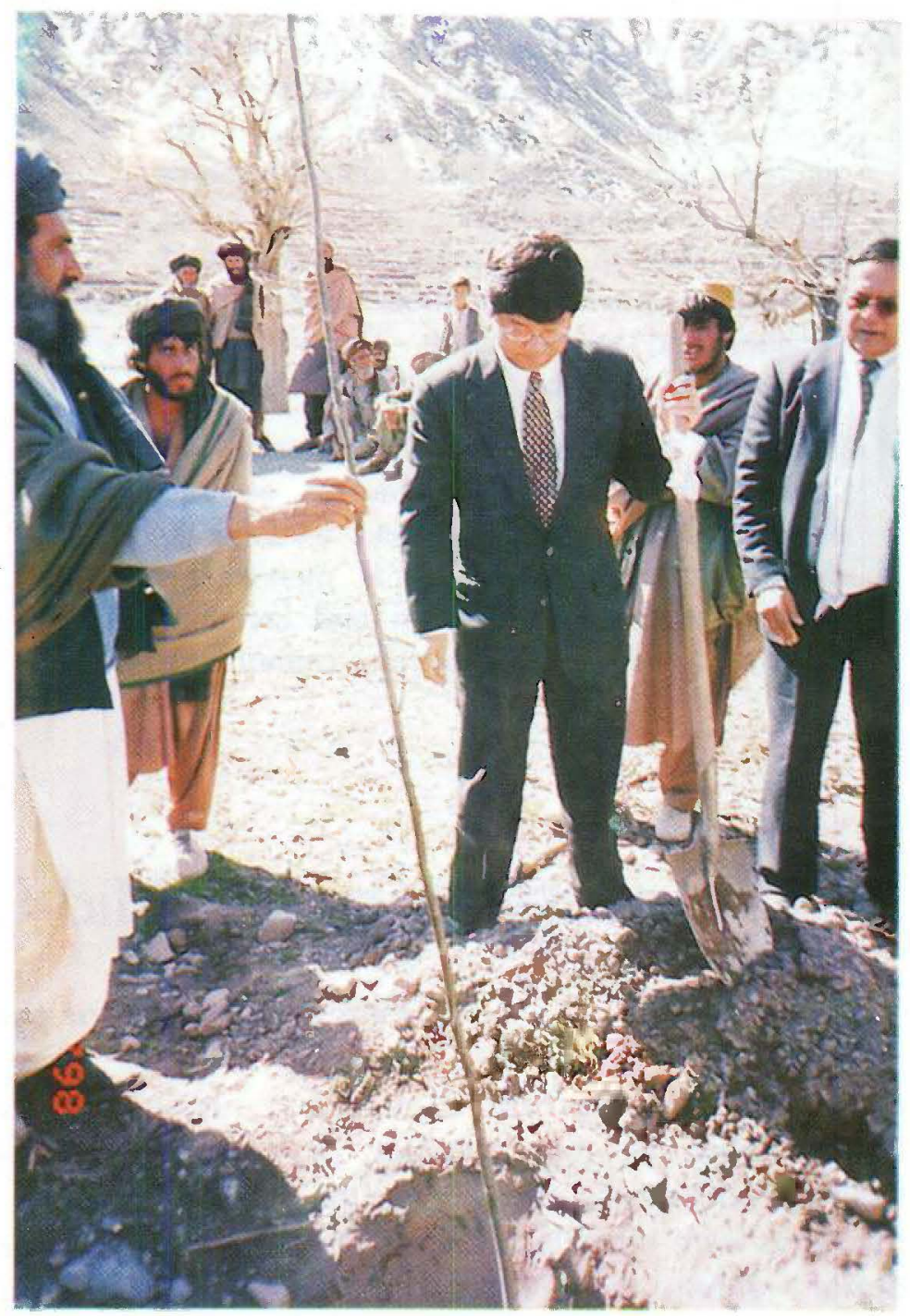

$\$ 0$

Planning the future 


\title{
MAKING IT WORK
}

\author{
Guided by: \\ Ahmed Farah
}

Chief of Mission, UNHCR Afghanistan

\section{Edited by:}

Dr. S. B. Ekanayake

Basic Education Adviser, UNHCR

\author{
Assisted by: \\ Yoshiyuki Yamamoto \\ Programme Coordinator, UNDP
}

Photography:

Surrendra Panday

Japanese Embassy

FAO

Editorial Comments:

Dr. (Mrs) Anjum Riyazul Haque, UNESCO

Rupert Colville, UNHCR

Formatted and designed by:

$M$. Anwar Husain

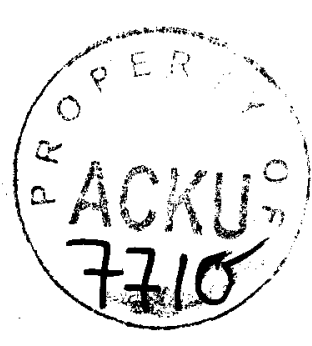

\section{ACKNOWLEDGEMENT}

This document was prepared at a short notice. In this effort, the editor acknowledges gratefully, the assistance provided by all those who had contributed to the completion of this document, without which "Voices in the mountains" would not have been heard, so readily.

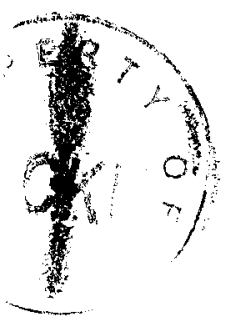




\section{References}

1. Minutes of review meeting of Azra-Tezin for the joint UN-Ahmed Farah, Oct. 1998

2. FAO Mission report to Azra and Tezin, 27 Oct. 1998

3. Population of Azra and Tezin - UNDP, May, 1998

4. Draft Bulletin, UNHCR Press Release, Rupert Colville, UNHCR, 15 May 1998.

5. Shelter programme under returnee reintegration programme in Azra and Tezin - March 1998

6. Friday Times, April 17-23, 1998

7. NEWS - 1 April 1998

8. Mid-term progress report on reintegration of returnees in Azra and Tezin, UNHCR - 1997

9. Revised frame-work for programme of activities in Azra, A. Daneshvar, UNHCR - 1997

10. Passage to Azra, S.B. Ekanayake, UNESCO, 1997. 